\title{
"LA FIDELIDAD, EL AMOR Y EL GOZO" LA JURA DEL REY FERNANDO VII (CARTAGO, 1809)
}

\author{
"LA FIDELIDAD, EL AMOR Y EL GOZO" \\ THE PLEDGE CEREMONY OF THE KING FERDINAND VII \\ (CARTAGO, 1809)
}

Guillermo Brenes Tencio*

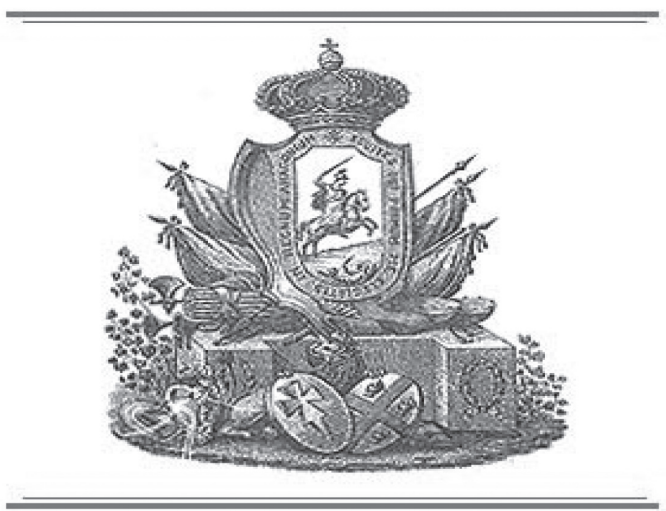

RESUMEN

Durante el período colonial, las fiestas reales convierten a las ciudades hispanoamericanas en el escenario público en que se representa el fascinante espectáculo del imaginario monárquico. Todas las colonias del Imperio Español en América proclamaban a un monarca físicamente ausente, pero materializado simbólicamente, a través de representaciones discursivas e iconográficas. En este trabajo, que tiene un carácter exploratorio, se describen y analizan los aspectos más interesantes de la proclamación o ceremonia de jura del Rey Fernando VII, en la ciudad colonial de Cartago, entre los días 15 y 23 de enero de 1809.

PALABRAS CLAVE: CARTAGO, CR * ANÁLISIS HISTÓRICO * ANTROPOLOGÍA SOCIAL Y CULTURAL $*$ SIMBOLISMO * PODER * HISTORIA COLONIAL 


\section{ABSTRACT}

During the colonial period, the royal celebrations made the Hispanic American cities the public scenario to represent the fascinating spectacle of the imaginary monarch. All the colonies of the Spanish Empire proclaimed a monarch who was physically absent but was symbolically materialized through discursive representations and iconographies. This article describes and analyzes the most interesting aspects of the proclamation or pledge ceremony of the King Ferdinand VII, which took place in the city of Cartago, between January $15^{\text {th }}$ and January $23^{\text {rd }}, 1809$.

KEY WORDS: CARTAGO, CR * HISTORICAL ANALYSIS * SOCIAL AND CULTURAL ANTHROPOLOGY * SYMBOLISM * POWER * COLONIAL HISTORY

\section{PRELIMINAR}

...el amor á la Religión, la fidelidad al Monarca, la unión entre el Rey y el vasallo por el amor $y$ temor de Dios que reina en los corazones de todos, es el norte de nuestras operaciones...

Fray Manuel de la Horta (1809).

La ceremonia de jura fue la celebración regia más importante del Antiguo Régimen, pues permitía, mediante la proclamación, la materialización de un monarca, incluso aunque estuviera físicamente ausente. El acto de "jurar" era manifestar fidelidad, lealtad y vasallaje al Rey, urbi et orbi, mediante las ceremonias al uso; empero, esta demostración debía ser pública. En efecto, no servía proclamar fidelidad si el acto no era público, de modo que la obligación de que se diera frente al conjunto de individuos, ayudaba a la concienciación de los vasallos de la Monarquía ${ }^{1}$. En América, la ceremonia de jura se impuso en el Virreinato del Perú y en el de la Nueva España ya desde el siglo XVI, celebrándose en las plazas mayores de todas las localidades $y$, sobre todo, las ciudades, que veían alterar agradablemente el diario trajín. Innegablemente, dicha ceremonia adquiría un significado harto especial en los

1 Véase: Víctor Gayol, 'El retrato del escondido. Notas sobre un retrato de jura de Fernando VII en Guadalajara", Relaciones. Estudios de Historia y Sociedad, 83, verano de 2000, pp. 151-181. reinos y provincias del Imperio Español. ¿Por qué? A diferencia de la Metrópolis Ibérica, los súbditos de Ultramar nunca tuvieron ocasión de conocer directamente a los reyes ni a los príncipes herederos, por lo que su proclamación devenía en la América Española en una suerte de presentación virtual del "pacto" entre los vasallos y el Rey, en la sociedad colonial ${ }^{2}$. Como parte de este acto, el cual se realizaba con la participación de todo el conjunto social, se lanzaban cientos de monedas y medallas conmemorativas a la jura y proclamación, las cuales mostraban en una de sus caras la efigie del Rey para darlo a conocer. En un sentido semejante, la ausencia física del Soberano durante la época colonial se subsanaba mediante la utilización de su imagen pintada en los rituales públicos, un dispositivo que Ernst H. Kantorowicz denomina "cuerpo del rey"3. Arte y propaganda se

Alejandra Osorio, El Rey en Lima. "El simulacro real $y$ el ejercicio del poder en la Lima del diecisiete", Documento de Trabajo 140, Instituto de Estudios Peruanos, Lima, 2004, p. 7.

3 Durante la fiesta y jura de proclamación, la iconografía y la simbología debían exponer y dejar clara la relación política que se adquiría el nuevo Rey. De acuerdo con este argumento, la asociación que construía el juramento era la forma en que se fundían los lazos políticos de la sociedad del Antiguo Régimen. El juramento establecía un pacto entre los agentes sociales que lo hacían; de ahí que a este tipo de práctica jurídico-ideológica se le denominara "sociedad pactista". Véase: Francisco Colom González, "El trono vacío. La imaginación política y la crisis constitucional de la Monarquía Hispánica”, 
combinaban para transformar estas celebraciones, eminentemente urbanas, en actos políticos de adhesión al servicio de la Monarquía Hispánica 4 . Era necesario, además, transmitir tal motivación a los demás sectores de la población. ¿Cuál fue la estrategia? Implementar actividades de reconocida participación pública, entre otras, el paseo del estandarte real, las escaramuzas y representaciones teatrales, los fuegos de artificio y luminarias, las corridas de toros, danzas y comparsas enmascaradas. Lo anterior supone que el espacio brindado por el esparcimiento era utilizado para promover una visión del mundo específica, que podía ser utilizada, para inculcar valores como el sincero amor y eterna lealtad al Rey. La lealtad de los súbditos de los inmensos dominios americanos se puso de relieve en el difícil trance que sufre la Corona Española en la convulsa primavera de 1808, año de la ascensión al trono del príncipe don Fernando, tras el motín del Real Sitio de Aranjuez (con réplica en Madrid), a raíz del cual su padre, Carlos IV, fue obligado a abdicar. A lo largo de trescientos años, las dinastías de los Austrias (nombre con el que se conoce también a los Habsburgo españoles) y los Borbones, que gobernaron el conglomerado que fue dado en llamar las "Indias Occidentales", lo habrían hecho desde la seguridad $y$ firmeza de un trono

Francisco Colom González, ed, Relatos de nación. La construcción de las identidades nacionales en el mundo hispánico, Iberoamericana-Vervuet, Madrid, 2005, pp. 23-50. Ivana Frasquet Miguel, "Alteza versus Majestad: el poder de la legitimidad en el Estado-nación mexicano: 1810-1824", Víctor Mínguez Cornelles y Manuel Chust, eds, El imperio sublevado. Monarquía y Naciones en España e Hispanoamérica, Consejo Superior de Investigaciones Científicas, Madrid, 2004, pp. 255-276. Ernst H. Kantorowicz, Los dos cuerpos del Rey, Alianza Universidad, Madrid, 1985. Marco Antonio Landavazo, "La sacralización del Rey. Fernando VII, la insurgencia novohispana y el derecho divino de los reyes", Revista de Indias, LXI (221), 2001, pp. 67-90.

Víctor Mínguez Cornelles, 'Fernando VII. Un rey imaginado para una nación inventada", Jaime Rodríguez, coord, Revolución, independencia y las nuevas naciones de América, Fundación MAPFRETAVERA, Madrid, 2005, pp.193-196. que nunca conoció amenazas externas que lo cuestionaran. Sin embargo, cuando Napoleón encierra a la familia real española en Bayona (Francia), y depone a Fernando VII, sustituyéndolo por su hermano José Bonaparte como rey, en junio de 1808, el trono se tambalea y la sensación de pertenecer a una monarquía imperecedera hace crisis. Así, al mismo tiempo que se enfrentaba a los invasores franceses, se convocaba a elección de diputados para gobernar en nombre de Fernando VII, y redactar la primera constitución escrita de España y su imperio ultramarino. La caída de la monarquía borbónica en 1808 significó, en suma, la desaparición del único referente de legitimidad trascendente conocido en el mundo hispánico. Esos inusitados acontecimientos fueron resistidos en la Península Ibérica y en sus colonias en América. Don Fernando de Borbón se convirtió, por pretensiones meramente políticas, en El Deseado, El Traicionado, o El Escondido ${ }^{5}$, entre otros muchos epítetos. Emocionalmente presionados, los súbditos americanos afirman su lealtad inquebrantable al rey cautivo por las fuerzas napoleónicas. De ahí que, probablemente, ningún otro festejo expresa con mayor elocuencia la lealtad de todas las ciudades y villas de las colonias hispanoamericanas, $y$ por consiguiente en Costa Rica, a su monarca, como la jura por don Fernando VII, el último Borbón que reinó en América. Los representantes de la Corona Española debieron sorprenderse por las manifestaciones nunca vistas de fidelidad al sistema político vigente $y$ de sumisión al legítimo soberano, las cuales se suceden en un marco temporal que abarca desde agosto de

Manuel Chust Calero, 'El Rey para el pueblo, la Constitución para la Nación”, Víctor Mínguez Cornelles y Manuel Chust, eds, El imperio sublevado. Monarquía y Naciones en España e Hispanoamérica, Consejo Superior de Investigaciones Científicas, Madrid, 2004, pp. 225-254. François-Xavier Guerra, Modernidad $e$ independencias. Ensayos sobre las revoluciones hispánicas, Fondo de Cultura Económica, México, 2000, Capítulo V. Juan Rafael Quesada Camacho, "El ideario de la Revolución Francesa en Cádiz: Aproximación al estudio de la construcción de la nación costarricense", Revista del Archivo Nacional, LXIX, 1-12, 2005, pp.105-155. 
1808 hasta principios de 1809; y que dependiendo de la riqueza del lugar podían ser fastuosas o sencillas ${ }^{6}$. Celo semejante sólo exhibió la autoridad eclesiástica al hacer cumplir con las cosas de Dios. Monarquía y Religión, he aquí las bases fundamentales del absolutismo. Unidad, en fin, político-religiosa, fundamentada en la adhesión a los valores de una monarquía concebida como una "Monarquía Católica"7. Por ello, en todos los actos públicos era denominador común la celebración religiosa, ya que invocar a Dios se identificaba como una forma de redención hacia el Monarca.

En el caso de la Provincia de Costa Rica, la cual estaba circunscrita al Reino de Guatemala $^{8}$, sus habitantes, hombres y mujeres, vecinos principales y del común, eran súbditos del Rey español y, por lo tanto, debieron adecuarse al rito festivo que estipulara la autoridad

Beatriz Rojas Nieto, Documentos para el estudio de la cultura política de la transición. Juras, poderes e instrucciones: Nueva España y la Capitanía General de Guatemala. 1808-1820, Instituto de Investigaciones Doctor José María Luis Mora, México, 2005, p.15.

Sandra Chavarría Jiménez, "Las estructuras de dominación en Costa Rica: de la época colonial a los albores del Estado Nacional”, Serie Nuestra Historia Nro. 6, Editorial de la Universidad Estatal a Distancia, San José, 1993. FrançoisXavier Guerra, et ál, Los espacios públicos en Iberoamérica. Ambigüedades y problemas. Siglos XVII-XIX, Fondo de Cultura Económica, México, 1998. Jaime Valenzuela Márquez, 'De las liturgias del poder al poder de las liturgias: para una antropología política de Chile colonial". Historia, 32, 1999, pp. 575-615.

En cuanto a la justicia, a lo político y a lo militar, la Gobernación de Costa Rica pertenecía a la Real Audiencia y Cancillería de Guatemala; en lo religioso, Costa Rica dependía del Obispado de León de Nicaragua. La primera demarcación de la Provincia de Costa Rica correspondía a capitulaciones que databan de las postrimerías del siglo XVI, las cuales se mantuvieron sin mayores cambios sino hasta después de la independencia, en 1821. El territorio de la provincia, se extendía desde el río Tempisque en la región del Pacífico Seco y el río San Juan en la zona del Caribe norte hasta la isla del Escudo de Veragua en Bocas del Toro por el lado del Caribe; $y$ hasta el río Chiriquí en el litoral Pacífico. No obstante, aunque estas monárquica de turno. Aparte de la jura de un nuevo monarca, se debían festejar otros eventos contingentes, como los esponsorios del rey, el nacimiento del primogénito $y$ de toda la prole, la alianza con otra monarquía, o los onomásticos reales. El ciclo festivo se cerraba con los lutos sumamente rigurosos por el rey muerto $y$, una vez cumplidos con estos, se celebraba la entronización del heredero, con el grito ritual: ¿El Rey ha muerto, viva el Rey! ${ }^{9}$. Las festividades combinaban rituales religiosos, políticos, militares $y$ variadas diversiones públicas. Ellas podían expresarse bien en gestos protocolares o en una representación teatral, en un sermón eclesiástico, en una pomposa procesión urbana o en la iluminación nocturna obligatoria — por varios días - de todas las casas de la ciudad. Asimismo, las festividades - conocidas como fiestas tradicionales o del "Antiguo Régimen"incluían expresiones artísticas efímeras, tales como tablados, arcos triunfales y máquinas de fuegos artificiales ${ }^{10}$. En tales ocasiones, la Plaza Mayor era adornada de acuerdo con las circunstancias, $y$ de noche era iluminada con antorchas para que se pudiera disfrutar de los

fueron las fronteras jurídico-administrativas de la Gobernación de Costa Rica, el dominio efectivo de los españoles asentados en Cartago era un espacio muy reducido, que se circunscribía principalmente al Valle Intermontano Central, la región del Pacífico seco y, en forma más precaria, a los territorios del Valle del Reventazón hasta el Caribe Central y la región del Pacífico Sur. Para ampliar: Juan Carlos Solórzano Fonseca, "La sociedad colonial 1575-1821", Ana María Botey Sobrado, coord. Costa Rica: desde las sociedades autóctonas hasta 1914, Editorial de la Universidad de Costa Rica, San José, 2002, pp. 115-172.

9 Véase especialmente: Franco Fernández Esquivel, La Plaza Mayor: génesis de la nación costarricense, Editorial Cultural Cartaginesa-Uruk Editores S.A., Cartago, 1996, Capítulo IV. Eva María Guevara Salazar, "Fiestas profanas en la sociedad colonial, Vida cotidiana en la Colonia. 16801821", Seminario de Graduación de Licenciatura en Historia, Universidad de Costa Rica, San José, 1994, pp. 48-183.

10 El modelo de fiesta que se inaugura en la América independiente utilizó, como paradigma, a las fiestas profanas o regias que acaecían hasta en los 
festejos por más horas. De ahí que el retiro para el descanso se producía más tarde de lo acostumbrado. Las autoridades políticas y las familias principales eran los actores principales y el resto de la población era principalmente espectadora y receptora del mensaje ${ }^{11}$. El espíritu de fiesta colectiva, que ligaba a los súbditos al rey distante, habría sido de esta forma recreado a través de fórmulas mínimas comunes a todo el Imperio Hispánico en América ${ }^{12}$.

En las siguientes líneas abordaremos cómo se desarrolló la fiesta de proclamación $y$ jura del Rey Fernando VII en la Cartago de $1809^{13}$, capital de la Gobernación de Costa Rica por más de 250 años y ciudad regente de cuanto acaeciera en la provincia, la más "marginal" y "alejada" de la capital del antiguo "Reyno de Guatemala". Esta situación, no está de más señalarlo, imponía severas restricciones a la vida económica y social de la Provincia de Costa Rica. Asimismo, interesa valorar como veta historiográfica una antropología de los rituales del poder, a partir del estudio "morfológico" de la fiesta regia en la sociedad colonial cartaginesa. Poder y fiesta se hallan de este modo en el centro de nuestras preocupaciones. El análisis del poder exige un reconocimiento de las formas en que este se expresa - a través de fiestas, rituales y ceremonias - en la vida social, no como una mera máscara o un pomposo adorno simbólico y estético, sino como un elemento fundamental que lo constituye. El poder, en

sitios más recónditos, para legitimar sus nuevas estructuras de poder.

11 María José Garrido Asperó, Fiestas cívicas históricas en la Ciudad de México: 1765-1823, Instituto de Investigaciones Doctor José María Luis Mora, México, 2006, p. 17.

12 Al respecto consúltese el pormenorizado trabajo de: Roberto Breña, El primer liberalismo español y los procesos de emancipación de América, 18081824. Una revisión historiográfica del liberalismo hispánico, El Colegio de México, México, 2006.

13 A mediados del siglo XVIII y principios del XIX, los vecinos de la ciudad de Cartago y su periferia festejaron el ascenso al trono de los siguientes monarcas de la dinastía borbónica: Luis I (1725), Fernando VI (1747), Carlos IV (1790), y Fernando VII (1809). suma, lo es porque se despliega mediante actos enfáticamente performativos ${ }^{14}$.

Desde épocas inmemoriales, la práctica fiesta ha acompañado la vida en sociedad. ¿Qué es una fiesta? En latín "festa" significa reunión para expresión de alegría. La fiesta es uno de los espacios más frecuentes en la práctica ritual de la representación simbólica. Sus ritos ceremoniales y su lenguaje simbólico reflejan el imbricado tejido de las relaciones que se establecen entre los actores en un determinado ordenamiento social ${ }^{15}$. No hay que pasar por alto el carácter colectivo e integrador de la fiesta, ya que en ella participan los notables, las instituciones y las gentes del común. De ahí que la fiesta se erige en un instrumento

Georges Balandier expresa contundentemente que: “... tras cualesquiera de las disposiciones que pueda adoptar la sociedad y la organización de los poderes encontraremos siempre presente a la 'teatrocracia'... los actores políticos deben pagar su cotidiano tributo a la teatralidad... Todo sistema de poder es un dispositivo destinado a producir efectos, entre ellos los comparables a las ilusiones que suscita la tramoya teatral”. Véase: Georges Balandier, El poder en escenas: de la representación del poder al poder de la representación, Paidós, Barcelona, 1994, p. 16.

Refiérase a los sugerentes estudios de: Bronislaw Baczko, Los imaginarios sociales. Memorias y esperanzas colectivas, Ediciones Nueva Visión, Buenos Aires, 2005. Mijail Bajtin, La cultura popular en la Edad Media y el Renacimiento: El contexto de François Rabelais, Alianza Editorial, Madrid, 1999. Roger Chartier, El mundo como representación. Historia cultural entre práctica y representación, Gedisa Editorial, Barcelona, 1995. Teresa Ferrer Valls, "La fiesta en el Siglo de Oro: en los márgenes de la ilusión teatral", Teatro y fiesta del Siglo del Oro en tierras europeas de los Austrias, SEACEX, Madrid, 2003, pp. 27-37. Juan Carlos Garavaglia, "Del Corpus a los toros: fiesta, ritual y sociedad en el Río de la Plata colonial", Anuario del IEHS, 16, 2001, pp. 391-420. María José Garrido Asperó, Fiestas cívicas históricas en la Ciudad de México: 1765-1823, Instituto de Investigaciones Doctor José María Luis Mora, México, 2006. Enrique Gil Calvo, El estado de fiesta. Feria, foro, corte y circo, Espasa-Calpe, Madrid, 1991. Marcos González Pérez, "Sociabilidad y fiesta. Bogotá, siglo XIX", Historias, 41, octubre-diciembre 1998, pp. 113-121. Juana Martínez Villa, "La fiesta regia en Valladolid de Michoacán. Política, sociedad 
dinamizador del ideario de representación y teatralización del poder. Verónica Zárate ha escrito que las fiestas rompen lo cotidiano, no reflejan una separación clara entre lo civil y lo religioso, entre lo profano y lo reverente, entre lo público de la celebración y lo privado de los sentimientos ${ }^{16}$.

Según la información documental disponible, la fiesta regia fue una ocasión especial para que los costarricas - gentilicio usado desde mediados del siglo XVIII hasta las cuatro primeras décadas del XIX- dieran pruebas contundentes de su aceptación, amor, obediencia, en fin, apego indiscutible al Rey, percibido como la "cabeza" legítima del imaginario monárquico durante el régimen colonial. Los "costarricas", al igual que muchos súbditos hispanoamericanos, demostraron su fidelidad y devoción a la monarquía ibérica, al otorgar su socorro económico a las milicias que defendían a España de la agresión francesa. Como recompensa a este gesto, el 16 de octubre de 1813, la ciudad de Cartago recibió el título honorífico de "Muy Noble y Muy Leal". ¡Premio a los buenos vasallos, por su acendrado patriotismo! Así, es indiscutible que hasta el momento en que se presentó la situación imprevista de la independencia en 1821, nadie en Costa Rica cuestionó la institución de la Monarquía. No hubo ni movimientos juntistas que reasumieran el poder soberano ni guerras por la independencia. Por el contrario, el 30 de mayo de 1821, los costarricas celebraron el onomástico de

y cultura en el México Borbónico", Tesis de Maestría en Historia, Instituto de Investigaciones Históricas, Universidad Michoacana de San Nicolás Hidalgo, México, 2006. Carlos Page,"Las proclamaciones reales en Córdoba del Tucumán", Revista Complutense de Historia de América, 30, 2004, pp. 77-94.

Verónica Zárate Toscano, "Del regocijo a la penitencia o del carnaval a la cuaresma en la Ciudad de México en el siglo XIX", Gonzalbo Aizpuru, Pilar y Verónica Zárate Toscano, coords., "Gozos y sufrimientos en la historia de México", El Colegio de México-Instituto de Investigaciones Dr. José María Luis Mora, México, 2007, p. 230.
Fernando VII, considerado por ellos como el mejor de los reyes ${ }^{17}$.

La fuente principal para el estudio de la fiesta por la jura y proclamación del Rey Fernando VII se encuentra en el minucioso documento/crónica elaborado por la pluma del Procurador Síndico General don Hermenegildo de Bonilla y Morales, en el año de 1809. Su lectura detenida ilustra sobre aspectos muy variados, relacionados con las celebraciones de carácter cívico/religioso y lúdico, por la monarquía en una provincia marginal, periférica y de falta de interés estratégico para la salvaguardia de la Metrópoli, como la Costa Rica de principios del siglo XIX. Hay que tener en cuenta que un ejemplar de la crónica del festejo se enviaba por obligación al Rey, para que este tuviera noticia de "cuanto se había hecho en su honor"; $y$ otro se incorporaba al libro de actas del Ayuntamiento o Cabildo. Así, la intención del Teniente General de los Reales Ejércitos y Gobernador y Comandante General por Su Majestad de la Provincia de Costa Rica, don Tomás de Acosta, fue la de

... dejar á posteridad testimonio auténtico de las festivas demostraciones hechas... por la exaltación de N. C. Rey y Señor don Fernando Séptimo al trono de la Monarquía de España, en la que por legítimo derecho se comprenden sus vastos dominios de América; $y$ perpetuar á nuestros descendientes las pruebas de amor y lealtad que hemos dado á nuestro amado soberano, aunque muy inferiores á nuestro deseo y fidelidad $^{18}$, [según sus propias palabras].

La "Relación de las Funciones hechas en Cartago en Proclamación de Fernando VII", fechada el 19 de junio de 1809, consta en el expediente 336 (del folio 153 al 157 v.) de la Serie Municipal Cartago, perteneciente a la

\footnotetext{
17 Juan Rafael Quesada, "El ideario”, p. 151.

18 ANCR, Sección Histórica (SH), Serie: Municipal Cartago, Expediente 336, 1809, fols. 119-120 v.
} 
Sección Histórica del Archivo Nacional de Costa Rica (en adelante ANCR) ${ }^{19}$.

\section{ENERO DE 1809. \\ CARTAGO JURA A SU REY DESEADO}

... no dudó, ni demoró Costa Rica tributar á su Augusto Monarca (Fernando VII) toda la obediencia, amor $y$ vasallaje que le es debido...

Tomás de Acosta (1809)

La muy noble, siempre fiel y católica ciudad de Santiago de Cartago - título oficial de la capital provincial- disfrutaba de una relativa tranquilidad cuando, el lunes 12 de septiembre del año 1808, llegó la noticia procedente de la Real Audiencia y Capitanía General de Guatemala ${ }^{20}$, de que la Corona de España y

Agradezco a la Dra. Beatriz Rojas Nieto (Instituto de Investigaciones Dr. José María Luis Mora, México), al Dr. Marco Antonio Landavazo y a la Mtra. Juana Martínez Villa (Universidad Michoacana de San Nicolás de Hidalgo, México), al Dr. Víctor Mínguez Cornelles (Universitat Jaume I, Castellón de la Plana, España), y al Dr. Jaime Valenzuela Márquez (Pontificia Universidad Católica de Chile), por su generoso apoyo bibliográfico $y$ valiosos comentarios a versiones preliminares de este trabajo. Extensivo a la Licda. Eva María Guevara Salazar y al Dr. Franco Fernández Esquivel, colegas y amigos. No obstante, los errores de forma y contenido son únicamente responsabilidad mía. Reconozco al personal del Archivo Nacional de Costa Rica (ANCR) la esmerada atención y el haber puesto a mi disposición sus ricos depósitos documentales.

El Reino de Guatemala, una capitanía general pretoriana gobernada por un capitán general y una audiencia, estaba compuesto por lo que hoy día es Centroamérica; es decir: Guatemala, Honduras, El Salvador, Nicaragua y Costa Rica. Además, comprendía también al actual estado de Chiapas, el cual se anexó a México después de la Independencia. A pesar de que contaba con un territorio que era mucho más extenso que el de España, era la jurisdicción más pequeña del continente americano. Con aproximadamente un millón de habitantes - alrededor de 40000 peninsulares y criollos, 313334 castas (pardos y negros), de Indias había quedado en poder de Napoleón I Bonaparte y sus ejércitos. Desde el 14 de agosto de aquel año, la capital del Reino había repudiado con vehemencia tan infausto suceso, al tenor de sermones eclesiásticos, bandos de gobierno y actas de cabildo. Como no podía ser de otra manera, tan pronto en Cartago se tuvo noticia de los sucesos de Bayona y de que España se encontraba bajo el control de Bonaparte, la reacción de los costarricas se desgranó, al igual que en otras latitudes americanas, en lealtad al joven rey y en repudio al emperador de los franceses. En efecto, el sábado 17 de septiembre de 1808 a las ocho de la mañana, el Gobernador don Tomás de Acosta y Hurtado de Mendoza (abril 1797 a 1809), convocó a una Junta de Autoridades y a los "vecinos principales" 21 de Cartago, con el fin de que, en la Sala del Muy Ilustre Cabildo, Justicia y Regimiento ${ }^{22}$, se discutieran las terribles circunstancias políticas por las que atravesaba la Monarquía Española. A pesar de la lealtad demostrada a la Corona, la situación desorientó a las autoridades del gobierno provincial. ¿Quién mandaba en España? ¿Quién, si es que había alguien, debía ser obedecido? ¿Qué debería hacerse? Después de escuchar diferentes criterios, se acordó en firme que, ante el forzado retiro del monarca reinante por medio de las armas napoleónicas, se considerara dicho acto como ilegal e inadmisible. Por tal motivo, se decretó, con una intensidad rayana en el delirio y el entusiasmo, renovar el juramento de fidelidad al Rey Fernando ("objeto y fin de la fiesta", al que se hace depositario de todas las virtudes y cualidades posibles, hasta el punto en que se llegó a la casi sacralización de su persona), y no admitir

646000 indígenas viviendo juntos y mezclados en quince ciudades $y$ villas de españoles, $y$ más de 800 pueblos de indígenas y ladinos - fue la parte más densamente poblada de la América española.

Expresión utilizada por los acaudalados y poderosos en el Cartago colonial, para diferenciarse de las "gentes del común".

$22 \quad$ El Cabildo de la ciudad de Cartago era la principal institución política de la Provincia de Costa Rica y estaba compuesto, en su totalidad, por los vecinos principales. 
a ninguna autoridad extranjera ${ }^{23}$. Y todavía hay otra prueba aun más contundente de la fuerza de los sentimientos de lealtad de los costarricas hacia el rey legítimo: el "Donativo Patriótico" entregado para colaborar en la financiación de la guerra contra el Corso $^{24}$. A la reunión del 17 de septiembre sólo asistieron veintisiete individuos avecindados en la capital colonial, incluyendo, entre otros, a don Tomás de Acosta, don Joaquín de Hidalgo, don Ramón Jiménez y Rodríguez de Robredo, y don Manuel de la Torre y Jiménez. Obviamente, no eran los artesanos o campesinos pobres, ni los indígenas, tampoco los mestizos, menos los esclavos, los

Encabezados por el Gobernador don Tomás de Acosta, los conspicuos asistentes a la reunión en la Sala Capitular “... unánimemente dijeron que no reconocen ni reconocerán jamás los actos de cesión hechos en Bayona de Francia por el Rey nuestro señor Carlos Cuarto y sus altezas reales el príncipe de Asturias y los señores infantes don Carlos y don Antonio, porque los tienen por desnudos de toda autoridad y fuerza extrínseca, por violentos, ilegales y por nulos en derecho... En su consecuencia renovaron todos el juramento de fidelidad y á las leyes que rigen, prometiendo guardar unión y conformidad con los magistrados, para conservar ilesa nuestra sagrada religión y mantener el buen orden y la tranquilidad pública. Al mismo tiempo protestaron no admitir ninguna autoridad extranjera...” Véase: ANCR, Sección Histórica (SH), Serie: Complementario Colonial, Expediente 991, 1808.

El 17 de octubre de 1808, el Gobernador don Tomás de Acosta publicó por bando la declaratoria de guerra de España al emperador Napoleón I Bonaparte, y el 20 de ese mismo mes, inició una recolección de donativos para colaborar en la financiación del esfuerzo bélico. Don Tomás de Acosta aportó la considerable cantidad de 100 pesos como muestra de patriotismo y como ejemplo para sus gobernados. Para diciembre de 1808 , se había recolectado un total de 215 pesos y 4 reales. La dádiva se depositaba en las cajas reales para que fuera remitida a España. Ligia Estrada Molina, "Don Tomás de Acosta: Gobernador de Costa Rica", Tesis de Licenciatura en Historia, Universidad de Costa Rica, San José, 1962, p. 126. Además, véase: ANCR, Sección Histórica ( $\mathrm{SH})$, Serie: Complementario Colonial, Expediente 919, 1808 y ANCR, Sección Histórica (SH), Serie: Municipal Cartago, Expediente 336, 1809, fol. 169 v. llamados a discutir y analizar la coyuntura política del momento. En oficio del 7 de octubre de 1808, el Capitán General y Presidente de la Real Audiencia de Guatemala, don Antonio González de Mollinedo y Saravia (1801-1811), comunicaba oficialmente a don Tomás de Acosta la "espontánea” abdicación del Rey Carlos IV y la orden de levantar pendones por su hijo, el Serenísimo Príncipe don Fernando de Borbón ${ }^{25}$. La prestación del juramento de fidelidad al nuevo rey se vio obstaculizada por el hecho de que el Cabildo de Cartago no estaba funcionando, por falta de regidores, $y$ no se podía disponer de fondos para sufragar los gastos de los festejos. El Gobernador, preocupado ante la posibilidad de que Costa Rica terminase siendo la última de las provincias que jurara lealtad al rey cautivo Fernando VII, consultó repetidas veces a la Capitanía y Real Audiencia de Guatemala, sin obtener una respuesta diligente. Tal y como lo expresó don Tomás de Acosta:

... por más fervientes que fuesen los deseos de [esta autoridad] en que se verificase la Proclamación de nuestro amado Rey y Señor con las formalidades de estilo $y$ debida solemnidad, se presentaba un reparo que obligó á retardarla. Este fue hallarse... el Ayuntamiento con las vacantes de todos sus empleados, existiendo solo el de Alcalde Provincial, por lo que se dudara á quien correspondía en tal caso hacer las funciones de Alferes Real, y el fondo que debía sufrir los gastos de la Proclamación, pues no habiendo en esta ciudad [de Cartago] quien lo pudiese decidir fue preciso consultarlo á la Superioridad 26 .

La organización y celebración de cualquier acontecimiento festivo demandaba una

25 ANCR, Sección Histórica (SH), Serie: Complementario Colonial, Expedientes 1102 y 1968, 1808.

26 ANCR, Sección Histórica (SH), Serie: Municipal Cartago, Expediente 336, 1809, fols. 153-153 v. De aquí en adelante, todo paréntesis así [ ] es mío. 
serie de egresos que en su mayor parte se sufragaban con los fondos de las cuentas del rubro de $\operatorname{propios}^{27}$, sin discutir si por ello quedaban paralizadas las obras públicas ${ }^{28}$. Sin embargo, en algunas oportunidades, el gobernador debía costearlos de su peculio, como en efecto sucedió, pues fue Acosta quien sufragó los gastos de los festejos ${ }^{29}$, temeroso de que las tempranas $y$ continuas lluvias los deslucieran. Pero quizá, en el fondo, había una cuestión de orgullo de don Tomás de Acosta, de probar ante sus gobernados su poderío, lealtad y acatamiento al Rey. Estas fiestas, que de su propio bolsillo costearon como muestra de un claro testimonio de "vasallaje, fidelidad, amor y obediencia" de cada súbdito a la figura todopoderosa que se tenía del Rey, se prolongaron por espacio de nueve días: desde el 15 al 23 de enero de $1809^{30}$. El domingo 8 de enero de 1809, una vez subsanado cualquier reparo, un bando del Gobernador Tomás de Acosta hizo público en Cartago el programa de las festividades, que habrán de iniciarse una semana más tarde, advirtiéndose

... que todos observasen solemnidad, pompa, buen orden, decoro y tranquilidad. [A los fines de procurar la moderación y el orden en los espectáculos y diversiones, la Gobernación dispuso] cerrar los estanquillos $[y]$ no vender una gota de aguardiente, bajo la pena de cinco pesos de multa ${ }^{31}$.

Fondos municipales provenientes básicamente del alquiler de tierras que permanecían bajo la administración del Cabildo.

Guevara, 'Fiestas profanas en la sociedad colonial", pp. 92-93.

ANCR, Sección Histórica (SH), Serie: Municipal Cartago, Expediente 336, 1809, fol. 165.

En el fondo, esta muestra de esplendidez del Gobernador don Tomás de Acosta se debió a que la consideraba una inversión provechosa que se recuperaba en forma de respeto popular y consolidación del poder.

31 ANCR, Sección Histórica, Serie: Municipal Cartago, Expediente 336, 1809, fols. 117-118 y ANCR, Sección Histórica, Serie: Complementario Colonial, Expedientes 993 y 994, 1809.
En este sentido, la legislación vigente resultó ser bastante drástica, por medio de ordenanzas que regulaban el comportamiento de los participantes, su indumentaria y el lugar que deberían ocupar en cada actividad, amenazando a los posibles transgresores con una serie de castigos y multas.

En los días festivos el ámbito urbano y sus protagonistas experimentaban cambios profundos en la ornamentación de los edificios, limpieza de calles, vestimentas especiales, e incluso, en la ejecución de una arquitectura efímera construida para la ocasión. De tal suerte que los vecinos de Cartago, distinguidos o no, debían ataviar e iluminar las puertas y ventanas de sus viviendas, talar los árboles de güitite ${ }^{32}$, encalar los edificios principales $y$ arreglar el tejado de los mismos, limpiar las calles y plazas, colocar arcos adornados con flores y empretilar las acequias; amén de vestir las mejores galas. Inmediatamente después, el señor Gobernador indicó a la oficialidad del Batallón, a los dependientes de la Real Hacienda, $y$ a los vecinos de los "lugares inmediatos" del Valle Intermontano Central, que les correspondía hacerse cargo de un día de funciones $^{33}$. La lejanía geográfica, respecto a los principales centros virreinales $y$ a la Audiencia de Guatemala, no era óbice, sino más bien acicate, que impidiera la realización de la fiesta. Indudablemente, las festividades más sonadas estarían auspiciadas por la Gobernación y por las familias cartaginesas más opulentas y las consideradas como de origen español. Además, en el mundillo de las representaciones sociales, los vecinos y las vecinas principales de Cartago eran los depositarios de las prebendas que gozaba una ciudad capital ${ }^{34}$, y los capitalinos

32 Güitite (Acnistus arborescens DC).

33 ANCR, Sección Histórica, Serie: Municipal Cartago, Expediente 336, 1809, fol. 123.

34 Arnaldo Moya Gutiérrez, "La vida cotidiana en la Provincia de Costa Rica. 1750-1820", Ana María Botey Sobrado, coord., Costa Rica: desde las sociedades autóctonas hasta 1914, Editorial de la Universidad de Costa Rica, San José, 2002, pp. 174-175. 
no disimulaban su desdeño hacia los advenedizos que habitaban el sector occidental del Valle Central de Costa Rica.

Es interesante señalar que, durante la época colonial, las noticias se transmitían a toda la población con el acompañamiento de cajas de guerra, clarines, tiros de fusil, tañido de campanas y aclamaciones al Rey. Dicha labor era llevada a cabo por el Teniente General, quien, junto con algunos miembros de las milicias, acompañaba al pregonero en su recorrido por las diversas calles y plazas de la ciudad, con el fin de que ningún vecino argumentara ignorancia y todos participaran de la celebración ${ }^{35}$.

Ante un evento de tal envergadura, don Tomás previno tajantemente a sus gobernados para que en la jura del Rey,

... todos los vecinos estantes y habitantes en esta ciudad [incluidas varias familias principales de Cartago]... que en todo tiempo dedicado al consabido fin, suspendan los lutos que tuviesen; $y$ que antes por el contrario, manifiesten con gala los sentimientos de alegría que mueven nuestros corazones á la mayor delicia, en actos tan debidos al Soberano, nuestro principal objeto ${ }^{36}$.

Como se habrá advertido, se trataba de una celebración atrasada que pretendía, según regia disposición, festejar la ascensión de don Fernando VII al trono español, demostrarle apoyo y reafirmarle el aprecio y la estima mientras estuviera prisionero en tierra extranjera. Por eso, a fuerza de demostrar su lealtad al distante e incuestionable Rey, el Gobernador Acosta - el más fiel de los súbditos reales- se empeñó en llevar adelante la jura de su obediencia, aunque fuese tardía, y la demostración de su encono a Napoleón. Así, la principal autoridad en el territorio de la Provincia de Costa Rica y de su capital, se empeñó en crear un ambiente festivo impuesto, producto de la

35 Guevara, 'Fiestas profanas", p. 60.

36 ANCR, Sección Histórica (SH), Serie: Municipal Cartago, Expediente 336, 1809, fol. 121. contingencia. La población se reunió en torno a la celebración de la Gobernación colonial cartaginesa, la que se encargó de que todo cuanto aconteciera en las reales fiestas fuese anotado, para "eterna memoria".

Un dato importante es que, en la época en que se realiza la real jura a Fernando VII, la ciudad de Cartago y sus arrabales contarían con poco más de 12000 habitantes, $y$ toda la provincia, con unas $50000 \mathrm{almas}^{37}$. Si la asistencia del público en los días de mayor solemnidad fue masiva, probablemente participó un $25 \%$ de esa población, de la cual los vecinos y vecinas distinguidos no debieron ser más de 600 sujetos. ¿Cómo era la fisonomía de la ciudad de Cartago en los albores de la centuria decimonónica? A principios del siglo XIX, la ciudad colonial de Cartago - cuyo asentamiento definitivo en el Valle de El Guarco data de $1575 \_{ }^{38}$, no había escapado a la simetría impuesta por las Leyes de Indias y mantenía las mismas características de otras ciudades españolas fundadas en América: se inscribía en el tipo de ciudad trazada en cuadrícula o damero, forma del tablero del juego de damas, que permitía una organización clara y simple de los elementos cívicos, ya fueran religiosos o político-administrativos. Sus edificaciones eran la mayoría de adobes o de mampostería, y cubiertas de tejas. Las vías principales de la ciudad capital, "orientadas" - en el estricto sentido de la palabra - hacia los cuatro puntos cardinales, eran rectilíneas y

Héctor Pérez Brignoli, Breve historia contemporánea de Costa Rica, Fondo de Cultura Económica, México, 1997, p. 24.

La ciudad de Cartago, antigua capital de Costa Rica, fue fundada en 1564 en un valle plano y arcilloso, ubicado en las faldas del volcán Irazú, y cerca de la confluencia de los ríos Taras, Coris y Purires. Las constantes lluvias convertían a la incipiente ciudad en un campo de lodo. En 1575, después de múltiples vicisitudes y traslados, fue reasentada en el sector noreste del Valle de El Guarco, en donde hoy día se encuentra. Para mayores detalles véase: Juan Carlos Solórzano Fonseca y Claudia Quirós Vargas, Costa Rica en el siglo XVI. Descubrimiento, exploración y conquista, Editorial de la Universidad de Costa Rica, San José, 2006, Capítulo VI. 
empedradas. La identificación de las calles de la Cartago colonial se hacía por medio de los nombres de los principales edificios públicos y de los vecinos de mayor ascendencia social. Algunos nombres utilizados fueron: la Calle de Juan Solano, la del Cabildo, la Calle de San Juan y la Calle de San Francisco. Por esas calles circulaban a diario caballos y carretas; $y$ quizá alguna silla de manos. Por otra parte, el agua era distribuida por todas las calles y solares mediante el uso de acequias o zanjas, que desaguaban los ríos adyacentes, cuyas fuentes se encontraban posiblemente al norte de Cartago ${ }^{39}$. Bien lo afirma el historiador costarricense Arnaldo Moya Gutiérrez, cuando apunta que ... para el visitante furtivo, conocedor de otras ciudades $y$ capitales [de la América Virreinal], la ciudad de Cartago no llamaría mucho su atención, y no motivaría registros significativos... ${ }^{40}$.

En el centro de la ciudad de Cartago destacaba la Plaza Principal frente a la que se ubicaba la Iglesia del Santo Patrono el Apóstol Santiago, ligeramente sobreelevada para darle una mayor relevancia en el contexto urbano. Y, en el frente noreste de dicha plaza, se ubicaba el Cabildo o Ayuntamiento, que tenía recintos para habitación del Gobernador, Contaduría, Cuartel de Milicias y Cárcel. El cementerio parroquial, reservado para individuos de baja condición social, se ubicaba en el solar de la Iglesia Mayor, y estaba rodeado de tapias. Por otra parte, en el cuadrante de la ciudad se levantaban las iglesias de San Francisco, San Nicolás de Tolentino y La Soledad. El cuadrante de Nuestra Señora de la Soledad también albergó al Hospital San Juan de Dios, regentado por los hermanos de dicha orden religiosa hasta 1799. Ya más hacia

Para ampliar, véase: Elizabeth Fonseca Corrales y Enrique Barascout, "Historia de la Arquitectura colonial", Elizabeth Fonseca Corrales y José Enrique Garnier, eds., Historia de la Arquitectura en Costa Rica, Fundación de Museos del Banco Central de Costa Rica, San José, 1998, pp. 81-149.

40 Arnaldo Moya Gutiérrez, 'La vida cotidiana en la Provincia de Costa Rica. 1750-1820", Ana María Botey Sobrado, coord., Costa Rica: desde las sociedades autóctonas hasta 1914, Editorial de la Universidad de Costa Rica, San José, 2002, p. 175. el este del damero urbano, se erigía la Iglesia de Nuestra Señora de los Ángeles. Alrededor de la Plaza Principal se ubicaron las casas solariegas de las familias acomodadas (incluyendo la vivienda oficial de los gobernadores $)^{41}$; y las más modestas albergaron a las castas: mestizos, indios, negros y castas, que al menos en la ciudad capital definieron sus espacios habitacionales en la Puebla de los Pardos y en el Barrio de San Juan de Herrera de Los Naboríos ${ }^{42}$. Sin ser muy extenso, el casco urbano cartaginés alojaba al señor gobernador y a las autoridades reales, así como a la jerarquía eclesiástica, al círculo de los vecinos prominentes y a las simples "gentes del común" 43 . Es este espacio urbano colonial el eje donde se tejían varias redes de sociabilidad, que alcanzaban su punto culminante durante los actos públicos. La vida holgada de la elite provincial se erigía sobre el trabajo abrumador de los esclavos negros y mulatos y de los indígenas, así como en la

Cada cuadra de la ciudad de Cartago se dividió en cuatro, cinco o seis propiedades. En la génesis de la capital provincial, cada solar ocupaba 2500 varas en cuadro (o lo que es lo mismo, un cuarto de manzana); pues era un privilegio de los vecinos principales que, descendientes de los conquistadores y primeros pobladores de las ciudades españolas en América, se les reconociera su rango - que era extensible a sus mujeres - mediante la ubicación de sus solares cerca de la Plaza e Iglesia Mayores. La elite colonial era legitimada en el poder a través de la concesión de puestos por parte de la Corona y le correspondía gobernar la Provincia de Costa Rica enteramente a su nombre.

42 Se seguía el lineamiento de la Corona Española, tendiente a mantener una sociedad segmentada: un núcleo español y barrios habitados por los indígenas y grupos de sangre mezclada o "castas". Sin embargo, toda esta política de separación étnica se vio afectada por el peso del mestizaje social y cultural, produciéndose una significativa hibridación entre españoles, indígenas y negros.

43 Para analizar el proceso de ocupación étnico-espacial de la ciudad colonial de Cartago y sus alrededores, véase: María de los Ángeles Acuña León y Doriam Chavarría, "El mestizaje: La sociedad multirracial en la ciudad de Cartago. 1738-1821", Tesis de Licenciatura en Historia, Universidad de Costa Rica, San José, 1991. 
exacción impuesta a los productores directos y a los artesanos. En este microcosmos colonial, aldeano, conservador e infundido de una fuerte raíz católica, la solemnidad de las funciones religiosas no eclipsó, de ninguna manera, las celebraciones profanas desplegadas en el espacio urbano del Cartago de principios del siglo $\mathrm{XIX}^{44}$. El espacio abierto de la Plaza Mayor, el atrio de la Iglesia Parroquial, sus escalinatas, los edificios que la rodeaban y las calles que allí desembocaban cumplían cada uno con una función en el desarrollo de la fiesta.

$¿$ Con qué funciones y regocijos se elogiaba a don Fernando VII el "Deseado"? La noche del 14 de enero de 1809, víspera de la proclamación del Rey, hubo repique general a vuelo en todas las iglesias de la ciudad de Cartago, salvas de artillería mayor, completa iluminación con velas de sebo o cera $y$ antorchas encendidas, gran número de cohetes, mascaradas, desfile de faroles y música por las arterias centrales, las cuales estaban limpias y acicaladas con guirnaldas y flores. Calles y plazas, solares de edificios públicos, iglesias o viviendas... Todos son espacios aptos para convertirse en lugar del espectáculo. Como bien puede suponerse, las festividades servían de pretexto para dar rienda suelta a los sentidos y las autoridades debían estar pendientes de tomar todas aquellas medidas conducentes a evitar el desorden. Esto queda evidente en la siguiente citación:

... Para que... hubiese el orden debido, dio el Gobernador las providencias correspondientes para que no faltasen Patrullas $y$ Rondas en la Ciudad y sus arrabales; asi se consiguió que en los nueve días de continua diversión no

El espacio para socializar, aparte de la misa, el mercado y las fiestas sacras y profanas, era limitado. En efecto, en las casas particulares se podían barajar cartas, jugar al truco (billar) y a las tablas (dados), o gozar de una tranquila velada, al calor de unos vinos o de un buen chocolate. Para ampliar: Franco Fernández, La Plaza Mayor, Capítulo IV. Eva María Guevara, 'Fiestas profanas en la sociedad colonial", pp. 48-183. hubiese el menor motivo para corregir á ninguno, ni siquiera arrestarle $e^{45}$.

El día 15 de enero de 1809 fue el más solemne. Dado que era importante sacralizar el acto ${ }^{46}$, a las nueve de la mañana, con todo el Venerable Estado Eclesiástico, se celebró una misa cantada de acción de gracias en la Iglesia Parroquial, en la cual se expuso el Santísimo Sacramento. A ella asistieron el Gobernador don Tomás de Acosta; los Alcaldes Ordinarios don José María de Peralta y La Vega y don Nicolás de Oreamuno y Sancho de Castañeda; el Síndico Procurador o "Representante del Común", don Hermenegildo de Bonilla; el Alcalde Provincial don Manuel de Marchena y Vargas-Machuca; los jefes y oficiales del Batallón Provincial; los miembros de las familias principales de Cartago, $y$ los otros agentes sociales convocados por el bando del Gobernador. A estos últimos se les coaccionaba a participar, de lo contrario, podía castigárseles severamente como enemigos traidores de la Real Corona ${ }^{47}$. A las puertas del templo del Apóstol Santiago, se encontraba formada la Compañía de Granaderos, capitaneada por don Joaquín de Oreamuno y Muñoz de la Trinidad, a la sazón, Alguacil Mayor, y vecino principal de Cartago. En la esplendorosa liturgia sacramental, rebosante de coros, flores, cera e incienso; Fray Manuel de la Horta ${ }^{48}$, con la cruz y el palio, pronunció - desde el púlpito- - un largo y conmovedor sermón religiosopolítico, en el que hinchió al "Rey Deseado" de sonoros elogios, y que terminó invocando la protección divina, junto a las ideas del pactismo social entre rey y vasallos. La lealtad al Rey es

ANCR, Sección Histórica (SH), Serie: Municipal Cartago, Expediente 336, 1809, fols.154-154 v.

Durante la época colonial, las celebraciones se desenvuelven sobre un itinerario que configura un espacio simbólico signado por lo religioso.

ANCR, Sección Histórica (SH), Serie: Complementario Colonial, Expediente 5339, 1809, fols. $1-1 v$.

48 Franciscano. Misionero Apostólico del Colegio de Cristo Crucificado de Guatemala. 
inseparable de la adhesión a la religión. En sus propias palabras:

... apenas habrá príncipe á quien se le haia intentado interceptar su exaltación al trono, con tan inicuos é infames medios como los que ha experimentado nuestro amado Fernando. Pero todo lo ha vencido la religiosidad y fidelidad de sus amados vasallos los que quando vieron á su amado Rey en manos de sus enemigos, despojado violentamente de la corona, á punto de espirar la dinastía de Borbón, entonces, entonces las Españas, las Américas, todos á la una aclamaron a nuestro oprimido $y$ amado Fernando, afianzando con la religión del juramento no conocer jamás otra Potestad. Á la aclamación se siguió el tomar generalmente las armas, exponer sus vidas para defensa de la religión, del Rey y de la Patria, con demostraciones tan extraordinarias, que darán el más auténtico testimonio en los tiempos por venir, que si no ha havido más aclamado. Ó Monarca piadoso! Ó Rey tan justamente deseado y aclamado de todos...Ó príncipe católico...ó amado Fernando...quantas desgracias nos ha acarreado tu ausencia! Pero quantas felicidades nos promete tu presencia, tu exaltación al Trono. Alégrate silla de San Pedro, alégrate que en el piadoso Fernando tienes un hijo humilde que respetará y obedecerá tus preceptos, un Monarca que será defensor y conservador de tu pureza y de tu doctrina. Alégrense los Ministros del Santuario, que en el nuevo reinado veremos destruidas las falsas ideas que tanto han oprimido nuestros corazones y que acaban de destruir la inmunidad eclesiástica. Alégrense los Militares que en Fernando VII tienen un monarca no despótico,... sino un Rey agradecido para premiarles sus fatigas. Alégrense los vasallos todos, pues en nuestro joven Fernando tenemos un príncipe que no nos oprimirá aumentando nuestras miserias, sino un Padre amoroso que continuamente dará las más oportunas providencias para aliviar nuestros trabajos. Espíritu consolador, distribuidor de todo lo bueno, derramad vuestros dones en nuestro amado Fernando, aumentadle más y más el amor á la religión, pues así será un Rey á la medida del corazón de Dios: llenad de bendiciones su reinado $y$ de felicidades á sus vasallos, y particularmente á esta siempre fiel y católica ciudad de Santiago de Cartago que... le ha aclamado con las demostraciones de la más sincera fidelidad y complacencia. Y por último, gran Dios, os pedimos con todo el afecto de nuestros corazones que después de haber reinado nuestro amado y augusto Fernando, en nuestra España, los dilatados años que le desea el Reverendo clero, el mui illustre Gobernador y Cabildo y demás individuos de esta ciudad y provincia de Costa Rica, meresca reinar por eternidades en la Gloria... ${ }^{49}$.

Es indudable la pretensión legitimadora y propagandística de la autoridad del monarca español a través del sermón religioso. Dentro del culto católico, el acto central de la misa lo constituye el sermón y el Te Deum es un agradecimiento al Creador, que forma parte del acto sacramental, cuyo testigo es Dios. La misa y el juramento corresponden a la visión tradicional del poder emanado de Dios; quienes lo detentan son responsables ante él. En este ambiente en que lo sagrado y lo cívico se confunden, las autoridades coloniales se presentaban al templo parroquial para dar gracias y recibir la protección del Todopoderoso; por su parte, la Iglesia Católica Romana recibía un reconocimiento como institución y mediadora adivina ${ }^{50}$. La Iglesia Parroquial debía estar completamente iluminada en el interior de todas sus naves y adornada con la magnificencia que exigía el acontecimiento. En el principio, intermedio y

\footnotetext{
49 ANCR, Sección Histórica (SH), Serie: Municipal Cartago, Expediente 336, 1809, fols. 124-130 v.

50 Juana Martínez Villa, La fiesta regia en Valladolid de Michoacán, p. 99.
} 
fin de la misa se hicieron salvas por parte de la Compañía de Granaderos. Debe considerarse que, con respecto a la concurrencia a la liturgia, no hay distinción entre los agentes sociales; empero, la elite colonial cartaginesa ocupaba el espacio interior de principal jerarquía cerca del altar mayor, mientras que el resto de la multitud ocupó los ámbitos y extensiones del templo. El asunto no terminaba allí. En esta disposición del espacio del templo, también se tomaba en cuenta la forma en que se había llegado hasta el sitio y con la que se saldría de él. Los distintos cuerpos se presentaban con una vestimenta especial, que exhibía rango y circunstancia. El orden $y$ el rango distinguen $y$ acercan a las personas reputadas por principales. Después de la solemne misa mayor y del Te Deum Laudamus, el Gobernador Acosta ofreció en su casa refrescos, mistelas y dulces ${ }^{51}$; $y$ de seguido, un opíparo almuerzo, al calor de la música de flautas, tambores, trompetas, campanillas y chirimías de indígenas danzantes de las reducciones o "pueblos de indios" de Cot, Quircot, Tobosi y el Naborío; quienes dejaban patente de esta forma — además de su lealtad simbólica al monarcasu voluntad por introducirse en el festejo.

Ya en la tarde, alrededor de las cuatro, se llevó a cabo el rito supremo de la fiesta: el juramento de fidelidad y la teofanía real. En la Sala Consistorial — donde, bajo un dosel de terciopelo carmesí, se mostraba el retrato (¿en lienzo?) del Rey Fernando VII ${ }^{52}$, y en un cojín la Real Corona- don Tomás de Acosta recibió de don Manuel de Marchena la lujosa bandera del Batallón Provincial, y se inició un solemne desfile militar - a caballo- por las engalanadas calles alrededor de la Plaza Principal.

Los refrigerios que se acostumbraban servir al concluir las actividades matutinas incluían tanto refrescos elaborados con el zumo de distintas frutas como las bebidas espirituosas. La mistela era una bebida hecha con aguardiente, mezclado con dulce y canela. Véase: Marjorie Ross González, Entre el comal y la olla. Fundamentos de gastronomía costarricense, Editorial de la Universidad Estatal a Distancia, San José, 2001, p. 88.

En el expediente se lee: “... Al pié del trono donde se puso el retrato de Su Majestad el día de la
Dentro de la simbólica del poder colonial, el paseo del Pendón Real o estandarte representaba un homenaje hacia la autoridad regia, en fin, una manera de patentizar obediencia, lealtad $y$ respeto al poder instituido ${ }^{53}$. Cuando no se contaba con el real lábaro, se acostumbraba hacer el despliegue de la bandera en las manifestaciones públicas, tal y como lo dispuso don Tomás de Acosta en 1809, tanto por ser la insignia que hemos de seguir á defender de los enemigos, quanto porque estando ya bendita se omitía esta ceremonia ${ }^{54}$. A la cabeza del desfile, marchaba el portero del Cabildo, el Batallón, los caballeros formando dos hileras que cubría ambos lados de las calles, $y$ por último, cerrando la escolta, el Gobernador con el Alcalde Primero y el Señor Coronel. Hacían parte del cortejo las justicias de los pueblos de indios, que animaban con sus insignias, melodías, ritmos y colorido original ${ }^{55}$.

La puesta en escena de los poderes se representó en el desfile, en el cual figuraban, claro está, las emperifolladas autoridades de la Provincia de Costa Rica y de los distintos pueblos indígenas colindantes, las compañías del Batallón, las bandas militares y los vecinos de distinción. Mas la plebe, como comparsa, también participó del evento, ubicándose en el espacio reservado por la costumbre. El orden en que cada uno de los actores sociales desfilaba, había sido asignado previamente, por mandato de la Gobernación. Probablemente, este precepto obedecía al interés de las autoridades de que no quedaran dudas de los sentimientos de fidelidad $y$ adhesión de los grupos subalternos hacia

proclamación, havía ocho décimas, en las que cada clase del Estado, esta Ciudad [de Cartago] y lugares próximos, tributaban al Soberano su lealtad, amor y obediencia". ANCR, Sección Histórica (SH), Serie: Municipal Cartago, Expediente 336, 1809, fol. $157 \mathrm{v}$.

53 Guevara, "Fiestas profanas", p. 104.

54 ANCR, Sección Histórica (SH), Serie: Municipal Cartago, Expediente 336, 1809, fol. 154.

55 ANCR, Sección Histórica (SH), Serie: Municipal Cartago, Expediente 336, 1809, fol. $127 v$. 
el régimen monárquico, representado por ellas, quienes desde su posición de cierre del desfile reafirmaban, en los espectadores, su obligación de doblegarse dócilmente al soberano español. En fin, un orden establecido que rendía culto a la monarquía, pero también a la estratificación social y étnica como soporte de las diferencias locales. Por ello, allí se podían observar tanto la unidad como la diferencia. Unidad que en el imaginario del Antiguo Régimen significaba la centralidad del poder monárquico, manifestación de lealtad, exaltación de la nación española. Diferencia en cuanto los privilegios, las posiciones, la participación reglamentada, controlada y jerarquizada.

¿Cuál fue el espacio cívico y tangible donde se celebró el desfile? El recorrido de la procesión por la capital colonial fue el siguiente: hacia el este, por la Calle Real o de la Sacristía, pasando por la calle llamada de doña Encarnación Trinidad; luego el desfile se dirigió hacia la derecha, por la calle de la Iglesia y convento de San Francisco. De allí, se continuó por las calles del Vía Crucis hasta la Iglesia de San Nicolás de Tolentino; y por último, los viandantes se dirigieron de nuevo desde la Calle Real hasta la Plaza Mayor, Real o de Armas ${ }^{56}$. La Plaza Mayor de Cartago constituía el corazón y centro obligado de las fiestas y las ceremonias del poder, de intercambio comercial, o del habitual trato común. Sería el lugar por antonomasia de todos encontrarse, ya fueran españoles, indígenas, mestizos, negros, mulatos o pardos. De allí el interés del cabildo local de mantener la plaza bien cuidada. En Cartago, esa tarea fue reservada a los indígenas, quienes se encargaban de acarrear tierra para nivelarla y mantenerla limpia ${ }^{57}$.

En la Plaza Mayor, se alzaba un tablado o estrado - construido por el gremio de carpinteros- cubierto con un dosel, desde el cual

56 ANCR, Sección Histórica (SH), Serie: Municipal Cartago, Expediente 336, 1809, fols. 154 -157.

Un interesante estudio sobre la Plaza Mayor de Cartago se encuentra en: Franco Fernández Esquivel, La Plaza Mayor, Capítulo I. el Alcalde Peralta y el Coronel del Batallón, don Juan Francisco de Bonilla y Morales, "Reyes de Armas", - por designación del Gobernadordaban jubilosamente los gritos de: "¿Cartago, Cartago, Castilla y las Indias por don Fernando VII!". La jerarquía de pertenencia está muy clara: la corona - Castilla_, el reino - las Indias-, la ciudad —Cartago-. Seguidamente, don Tomás de Acosta pronunció, con clara y alta voz, el solemne juramento de fidelidad. El Gobernador repetía la fórmula por tres veces desde diversos ángulos del estrado, al mismo tiempo que hacía "tremolar" el Real Pendón con energía ${ }^{58}$. Las demás autoridades contestaban "Amén", y al unísono, las gargantas de los colonos cartagineses pronunciaron la sencilla frase ritual, manifestando de ese modo la aceptación del monarca. Sin duda alguna, las vivas de la multitud constituían la expresión oral de entusiasmo y adhesión al poder monárquico. Si bien los funcionarios de la administración colonial desfilaban por las calles, finalmente se situaban en el tablado, en representación de su autoridad. Las autoridades y notables eran colocados por encima de los espectadores que reconocían y aceptaban su potestad, reafirmando con ello la pertenencia a la Corona Española.

El tablado constituía una importantísima parte del festejo. Colocado en el centro de la Plaza Mayor, rodeado de gradas y profusamente decorado con telas vistosas, flores, palmas y adornos diversos, debía lucir como un gran cuadro vivo, gracias a la animación que le proporcionaba el público con sus actuaciones. Es posible visualizar la escena como una verdadera apoteosis ante la imagen del regio personaje y el significado virtual que tenía para los presentes, además de lo ensordecedor de la misma. Tras

El pendón era una bandera o estandarte pequeño, de carácter militar, más ancho que largo. Se usaba en todas las actividades relacionadas con la monarquía. El alzamiento y tremolación del pendón real era un rito fundamental, realizado en todos los rincones urbanos del Imperio Colonial Español. La manipulación ritual del pendón para estas ocasiones se insertaba en el juego metafórico del renacer de la Monarquía. 
el juramento, se arrojaron "muchos puñados de dinero" $" 59$ al público entusiasmado hasta el arrebato, entre el tronar de la fusilería y el prolongado tañido de las campanas ${ }^{60}$. Este acto, de innegable impacto en la muchedumbre, debió ser un acontecimiento memorable, no sólo para aquellos afortunados que lograran recoger alguna de las monedas, sino también para todo aquel que presenciase una escena de connotaciones evidentemente socio dramáticas. Era un rito que permitía, en fin, incitar la continuidad de los gritos y aplausos de los espectadores. Además, su importancia se verá realzada si se tiene en cuenta la escasez de metálico que sufría la marginal y alejada Gobernación de Costa Rica ${ }^{61}$. El homenaje de la ciudad se mudaba, simbólicamente, en un pronunciamiento de lealtad al Rey "impersonal". Mientras la gente vivaba al Rey Fernando, se efectuaba con el despliegue del estandarte del Batallón, un majestuoso desfile alrededor de la Plaza de Armas, el cual concluyó en la sede del Cabildo de Cartago. Acto continuo, don Tomás de Acosta convidó a los concurrentes a un delicado refresco de cuanto franquea el país; $y$ a eso de las siete de la noche, dio inicio en la misma plaza una vistosa función de fuegos de artificio, que no podían faltar en estas celebraciones. Se presentaron varias figuras alusivas que ardieron dando luces multicolores. Tal fue el caso de un "famoso castillo" de cuatro cuerpos que fue quemado, quedando en su parte superior encendida por varios minutos una consigna que decía: ;VIVA EL REY FERNANDO VII!, novedad muy aplaudida por los asistentes. Para finalizar, alrededor de las diez y media de la noche, se iluminó una Corona (símbolo de la auctorictas real) con dos banderas a sus lados, una con el escudo

59 Posiblemente, se trataba de monedas de plata de un real.

60 ANCR, Sección Histórica (SH), Serie: Municipal Cartago, Expediente 336, 1809, fols.154-157.

61 Manuel Benito Chacón Hidalgo, Monedas de Costa Rica. Reseña histórica, Editorial de la Universidad de Costa Rica-Fundación Museos del Banco Central de Costa Rica, San José, 2003, pp. 32-33. de las armas reales y la otra con el de la ciudad de Cartago. Con las luminarias y los fuegos artificiales, que transcurrieron sin la menor desgracia, ni desorden, se pretendía dar a las noches el brillo que durante el día la luz del Sol prodigaba al decorado urbano. Muy elocuente es el hecho de que, durante toda la noche y a la luz mortecina de las velas, estuvo abierta la Sala Capitular donde estuvo expuesto el retrato de Su Majestad, acompañado de un regimiento de honor. Y, por extraño que pueda parecer, toda la madrugada los vecinos de Cartago llegaron hasta el recinto, con el fin de rendir "culto" a la áulica imagen borbónica. Probablemente, la gente se acercaba a la efigie y le hablaba: unos para consolarlo, otros para darle ánimos y otros más para fulminar rayos contra Napoleón y los "impíos" franceses. Dicho acto es, por supuesto, de carácter ritual y simbólico ${ }^{62}$. Al respecto, como bien lo expresa Roger Chartier:

... la representación se transforma en una máquina de fabricar respeto y sumisión, en un instrumento que produce una coacción interiorizada, necesaria allí donde falla el posible recurso a la fuerza bruta 63 .

Estos aspectos se pueden ampliar en: Víctor Gayol, "El retrato del Escondido. Notas sobre un retrato de jura de Fernando VII en Guadalajara", pp. 151-181. Marco Antonio Landavazo, La máscara de Fernando VII. Discurso e imaginario monárquicos en una época de crisis. Nueva España 1808-1822, El Colegio de México-Universidad Michoacana de San Nicolás de Hidalgo-El Colegio de Michoacán, México, 2001, pp. 59-221. Juana Martínez Villa, "La fiesta regia en Valladolid de Michoacán. Política, sociedad y cultura en el México Borbónico", Tesis de Maestría en Historia, Instituto de Investigaciones Históricas, Universidad Michoacana, México, 2006. Víctor Mínguez Cornelles, 'Fernando VII. Un rey imaginado para una nación inventada”, pp. 193-196.

Roger Chartier, El mundo como representación, p. 59. Además, véase: Serge Gruzinski, La guerra de las imágenes. De Cristóbal Colón a Blade Runner. 1492-2019, Fondo de Cultura Económica, México, 1990 , p. 146 . 
El lunes 16 continuaron los festejos. En la mañana, después de dispararse cohetes y tocarse diversas piezas musicales, se efectuó un apretado desfile, por las principales calles de Cartago, con los toros bravos que habrían de correrse por la tarde, a cuyo término, don Tomás de Acosta ofreció un bufé en su residencia. A eso de las tres de la tarde, se presentaron en la Plaza Mayor las máscaras, "diabladas" o "mojigangas", en las que participaban, habitualmente, indígenas danzantes estrafalariamente disfrazados de animales, monstruos y demonios, acompañados de la música de cajas, violines, tambores, campanillas y chirimías, y el tronar de los cohetes ${ }^{64}$. La participación de los danzantes puede interpretarse como una manifestación de su "lealtad" a la monarquía hispánica y una oportunidad para los indígenas de expresar públicamente sus tradiciones e identidades. Inmediatamente después de las mascaradas, se inició la corrida de toros. En el toril — ubicado en la Plaza Principal, ya que no existían lugares construidos específicamente para este tipo de espectáculo-, se hacían presentes desde las más altas dignidades civiles y eclesiásticas hasta los mestizos, españoles pobres, negros, mulatos e indígenas, todos participando con gran alegría. Se lidiaban y ensillaban un promedio de cuatro a cinco toros por corrida. Sin ninguna duda, la fiesta taurina servía de solaz tanto para los que participaban en las faenas de a pie, como para aquellos personajes más conspicuos que se regocijaban haciendo alarde de sus mejores caballos y riquísimas sillas de montar galoneadas de plata; amén de demostrar su riqueza, fuerza y destreza ecuestre ${ }^{65}$. Llegada la noche, el Gobernador ofreció un prolongado $y$ alegre sarao amenizado por dos bandas musicales, en donde se bailaban zarabandas y chaconas, al son de violines, castañuelas, guitarras $y$ panderetas. Al baile concurrieron en pleno las señoras y sujetos distinguidos de Cartago, vestidos con sus mejores indumentarias. Riquísimos tejidos, colores, joyas y aderezos que, al tiempo

Guevara, "Fiestas profanas", p. 65.

65

Fernández, La Plaza Mayor, pp. 76-77. que manifestaban la solvencia económica de los vecinos $y$ damas principales, revelaban la representatividad de los portadores. El arreglo de la casa del Gobernador, visible sólo para la elite colonial cartaginesa en pleno, fue el siguiente: ... sala bien iluminada... y todo con el mayor aparato, orden y simetría. A la medianoche se sirvió un "ambigú" o bufé de elaborados manjares calientes y fríos. Como se habrá advertido, la ingesta de alimentos y bebidas era un elemento muy importante, que acompañaba todas las celebraciones del poder. El baile, presidido por la efigie fernandina, se extendió hasta las tres de la madrugada del martes ${ }^{66}$. Valga destacar que el retrato del Rey era la personificación del poder distante, $y$ ante él, la gente debía brindar las más variadas muestras de "lealtad, amor y obediencia”.

A partir del martes 17 de enero, el Batallón Provincial tomó a su cargo los festejos, y se realizó el acostumbrado desfile callejero con toros, y en la tarde, se verificó la lidia. La corrida de toros, con gran asistencia de público, fue dirigida por el Capitán don Joaquín de Oreamuno, debido a la ausencia fortuita del Gobernador. Otro tipo de espectáculo escenificado en la Plaza Mayor, era el que consistía en un simulacro bélico, de origen señorial/ medieval, que enfrentaba ejércitos, con frecuencia de "Moros y Cristianos", también llamado "morismas", o que enfrentaba a indígenas contra españoles. En la escaramuza organizada en Cartago, en ese mismo día, participaron cuatro cuadrillas compuestas de mestizos y gentes de color (negros, mulatos, zambos y otras castas $)^{67}$, dos vestidas a la usanza española, $y$ las otras a la amazona; quienes exhibieron mucha

66 ANCR, Sección Histórica (SH), Serie: Municipal Cartago, Expediente 336, 1809, fol. 156.

67 Para celebrar la jura de Fernando VII, "quatro cuadrillas de mestizos y gentes de color no pudiendo costear ninguna... función en obsequio del Soberano pidieron se les permitiese [hacer esta escaramuza] en demostración de su regocijo y respetuoso amor”. ANCR, Sección Histórica (SH), Serie: Municipal Cartago, Expediente 336, 1809, fol. $155 \mathrm{v}$. 
agilidad, buen orden y buen gusto. En estos encuentros, los supuestos combatientes competían en cuatro tipos de sorteos: bohordos, estafemas, sortijas y el juego de cañas. Tamaño espectáculo a veces incluía también elementos de escenografía efímera, como galeras móviles $y$ castillos $^{68}$. Al anochecer, se llevó a cabo un nuevo y pomposo baile para los notables, con cena incluida, que se consumó a las tres de la mañana del jueves. Las fiestas reales continuaron en los siguientes días y su desarrollo se confió a los vecinos de las otras tres poblaciones principales del Valle Central de Costa Rica: Villa Vieja de Cubujuquí (la actual Heredia, 1714), Villa Nueva de la Boca del Monte (la actual San José, 1737) y Villa Hermosa (la actual Alajuela, $1782)^{69}$. Los vecinos pudientes de la Villa Nueva se encargaron de las festividades del 19. El día 20, la fiesta estaba destinada a los vecinos de Villa Vieja, la del 21 estuvo a cargo de los vecinos de la Villa Hermosa ${ }^{70}$. Todavía el domingo

Para ampliar: Juan Carlos Calderón Gómez, 'Moros y Cristianos en Cartago (Baile de Conquista)", Escena, 13 (27), 1991, pp. 20-25.

ANCR, Sección Histórica (SH), Serie: Municipal Cartago, Expediente 336, 1809, fols. 156v-157. Sobre el surgimiento de las ciudades de San José, Heredia y Alajuela véase: Carlos Meléndez Chaverri, "Las Villas Nuevas en la Costa Rica Borbónica", Luis Fernando Sibaja, et ál., Costa Rica Colonial, Ediciones Guayacán San José, 1989, pp. 165-177. Carlos Molina Montes de Oca, Y las mulas no durmieron...Los arrieros en Costa Rica. Siglos XVI al $X I X$, Editorial de la Universidad Estatal a Distancia, San José, 2005, pp. 455-462.

Los días más solemnes de la jura del Rey Fernando VII estuvieron bajo el auspicio del Gobernador don Tomás de Acosta, y el resto, como quien dice los días menos representativos, estuvieron bajo el patrocinio de los principales vecinos de Villa Hermosa, Villa Vieja y Villa Nueva. En las fiestas del 19 de enero de 1809, encomendadas a los notables de Villa Nueva, hubo desfile taurino, torneos $y$ escaramuzas, $y$ corrida de toros; $y$ por la noche, un baile que duró hasta la madrugada. El 20 le tocó el turno a las autoridades de la Villa Vieja, quienes repitieron el desfile de toros y demás, pero cuyo sarao, acompañado de una comida espléndida, se prolongó hasta el amanecer. Las fiestas del 21, a cargo de los vecinos de Villa Hermosa, no
22 de enero de 1809, siguieron las fiestas en Cartago. Los veteranos del Batallón Provincial se encargaron de realizar otra vez desfile con toros bravos, espectáculo, corrida, y alegre y prolongado sarao. Las actividades que se produjeron estaban íntimamente ligadas con el rito que les dio inicio: la jura. Cada grupo social expresó, a través de distintas formas, su adhesión al Rey Fernando, y con ello, demostraba su inquebrantable lealtad al rey preso en Bayona. En teoría, el escenario festivo pertenecía a todos y todos podían convivir en él, pero en la realidad lo hacían bajo el ojo vigilante de las autoridades $y$ con una separación bien marcada.

Para clausurar el estado de fiesta, y dejar sellada la lealtad a Fernando VII y el odio a Bonaparte, en un tablado erigido frente a la Sala Capitular, el cual se encontraba bien iluminado y revestido de cortinajes, se realizó en la noche del 23 de enero de 1809 una loa y un entremés o comedia, en los que se expuso, ante un numeroso concurso, un canto de alabanza al monarca legítimo y una imprecación al emperador de los franceses ${ }^{71}$. No cabe duda de que las representaciones escénicas provocaban un impacto visual muy importante ante una sociedad mayoritariamente iletrada. Justamente, el interés de tales actos radicaba en hacer visibles, a través de varios personajes, la legitimidad del reinado de Fernando VII y, consecuentemente, lo ilegítimo del de Bonaparte. El lenguaje

modificaron el programa de los días anteriores, y su baile llegó hasta las luces del alba. ANCR, Sección Histórica (SH), Serie: Municipal Cartago, Expediente 336, 1809, fols. 156-156 v.

71 Don Joaquín de Oreamuno y Muñoz de la Trinidad escribió la Loa nro. 4 y los Entremeses nro. 5 y nro. 6 , que se representaron con todas las formalidades del caso, por un grupo de jóvenes distinguidos de la ciudad de Cartago. ANCR, Sección Histórica (SH), Serie: Municipal Cartago, Expediente 336, 1809, fol. 157. Para ampliar: Jorge Francisco Sáenz Carbonelli, "iViva nuestro Rey Fernando! (Albores del teatro costarricense)", Revista Nacional de Cultura, 27, 1995, pp. 55-81. La loa y el entremés teatral se reproducen en su totalidad en: Sección Documental. "Teatro Colonial", Revista de Historia, 34, julio-diciembre 1996, pp. 179-221. 
utilizado reflejaba, además, la recurrencia a la divinidad como sostén del poder colonial e imperial. A modo de ejemplo, uno de los actores, disfrazado de soldado, arengó vehementemente mientras lo acompañaban los acordes de la música de timbales, flautas, trompetas, violines y guitarras:

Novilisimos Señores/ de la Ciudad de Cartago/ bendecid á Dios en pago/ de que os hace mil favores/ Regocijad con agrado al Poderoso Criador que os ha dado por favor la Rey que hoy habeis jurado/ A Dios por todo alabando siga la mucica y diga/ Que eternas edades viva/ nuestro invicto Rey Fernando/ No cesen los parabienes/ ni la gloria popular/ por la diadema Imperial/ que hoy fixa el Rey en sienes/Viva nuestro Rey Jurado/ Fernando VII en modo que del universo/ sea aplaudido y exaltado/ en todo el orbe se diga/ con solo una voz y un bando/ triunfe y reyne don Fernando/ y eternas edades viva ${ }^{72}$.

Y, aún más resulta elocuente el entusiasmo desbordado de las masas espectadoras cuando, en el clímax del entremés, se quema una grotesca figura que representaba al "pérfido” Napoleón. ¿Auguraría esta representación en la Plaza Mayor, convertida literalmente en un teatro, la caída del régimen napoleónico?

Al terminar el entremés - según narra vívidamente el historiador y cronista cartaginés Manuel de Jesús Jiménez Oreamuno (1854-1916) en el cuadro costumbrista "Fiestas Reales"-

resonaron en la Plaza de Cartago largo rato los aplausos, $y$ en verdad que no eran infundados. El muñeco había ardido en grandes llamaradas y estallado el gran bombón de su cabeza. El Coloso había quedado desquiciado en Bailén y

ANCR, Sección Histórica (SH), Serie: Municipal Cartago, Expediente 336, 1809, fols. 131-152 v.
Talavera, y ya se veía en lontananza a Waterloo ${ }^{73}$.

Acompañaba, a la ya tan de por sí metafórica puesta en escena, el siguiente cuarteto, que a la letra dice:

Así como arde este fuego arden los nobles vasallos su amor $y$ digan todos: viva nuestro Rey Fernando ${ }^{74}$.

Estas citas, espigadas entre muchas otras, además de poner de relieve el sentimiento de los vecinos de Cartago por su "Augusto Monarca”, evidencian magníficamente el poder de las imágenes como instrumentos causantes de una catarsis colectiva, con un eficaz apoyo acústico y musical. El espectáculo estuvo asociado con el creciente fervor que invadía las almas de los fieles patriotas. Dentro de una estructura simbólica, la crónica reproduce el orden social. En torno al tablado se instalaron cómodos palcos y galerías para las rancias familias principales, $y$ los individuos de baja condición social desbordaban los distintos puntos de la Plaza Mayor. No está de más reiterarlo: se trataba de una sociedad diferenciada, donde los factores de prestigio y representación eran fundamentales.

Con nutridos aplausos, jubilosas y continuas vivas al monarca cautivo en Francia, músicas, juegos de pólvora, el estruendo de la fusilería y el alegre repique de las campanas, la mayoría de los habitantes de la recoleta ciudad de Cartago se sumía en una atmósfera de rutina y sosiego, que quizá purgaba $y$ disimulaba - a través de lo lúdico- la tensión social incubada, día tras día, en la casa y en la comunidad; así como al calor del duro trabajo en las parcelas o en los talleres ${ }^{75}$. Esclavos, artesanos,

73 Manuel de Jesús Jiménez Oreamuno, "Fiestas Reales", Noticias de Antaño, Imprenta Nacional, San José, 1946, p. 67.

ANCR, Sección Histórica (SH), Serie: Municipal Cartago, Expediente 336, 1809, fols. 131-152 v.

75

Véase: Patricia Alvarenga Venotulo, "Resistencia campesina y formación del mercado de bienes básicos. Cartago. 1750-1820", Revista de Historia, 
campesinos y peones, sobre los cuales recaía el peso de las actividades productivas, sostenían el estilo de vida señorial de la elite colonial cartaginesa, que aprovechaba el universo festivo para legitimar su dominio $y$ exhibir su preeminencia.

\section{COLOFÓN}

En definitiva, a través de lo expuesto en este trabajo, se puede argumentar que las escenificaciones del poder en la sociedad colonial giraban en torno a dos grandes dispositivos estrechamente vinculados: la Monarquía y la Iglesia Católica Romana. La fiesta tiene una fuerza ambivalente que provoca una fortísima tensión entre lo sagrado y lo profano. Así, la celebración y el gozo originados por el juramento de fidelidad incondicional al poder monárquico, solían iniciar con un Te Deum solemne, seguido de una procesión de funcionarios civiles y religiosos. El ámbito central de las festividades de 1809 fue la Plaza Mayor de Cartago, aunque compartido con la Iglesia Parroquial y el Cabildo, inseparables emblemas del poder hispánico. Poder que prácticamente quedó impregnado en el rito, el sermón y en la utilización del espacio durante las ceremonias. La fiesta multitudinaria de aclamación al trono del Rey Fernando VII posibilitó, de una parte, romper - por diversos que fueran los oficios $y$ las experiencias - la habitual "vida monótona" de la capital de la Provincia de Costa Rica y, de otra; se constituyó en instrumento fundamental de un orden económico y social que se presentaba inamovible e inmutable. Según don Tomás de Acosta, los súbditos cartagineses estaban prestos ... á verter su sangre en defensa de la Religión que profesaban; del Rey

31, enero-junio 1995, pp. 41-67. Clotilde Benavides Murillo, "Reflexiones sobre la formación y función social de los artesanos en Cartago en el siglo XVIII", Revista Estudios, 18-19, 2004-2005, pp. 25-38. Iván Molina Jiménez, Costa Rica (1800-1850). El legado colonial y la génesis del capitalismo, Editorial de la Universidad de Costa Rica, San José, 1991. que han jurado; y de su Patria que aman ${ }^{76}$. La lealtad y la obediencia hacia la "Religión, el Rey y la Patria" expresaba, en fin, un vínculo directo con Dios, la Corona y su Rey; y se refería a todos los dilatados dominios de la monarquía española. Una fiesta del rango y solemnidad que significaba la reiteración de lealtad a un monarca forzosamente abdicado (pero cuya abdicación habían desconocido las autoridades locales, hay que recordar), alcanzaba, evidentemente, a todo el conjunto social y a individuos de toda condición. Es sabido que todo orden social se asienta, entre otras cosas, en un sistema de ritos y símbolos que son funcionales a la creación, consolidación y mantenimiento de dicho orden ${ }^{77}$. Por ello, aunque la presencia del Rey no gravitaba en la ciudad de Cartago de manera directa, su imagen era obligatoria en las ceremonias festivas que día a día se sucedían: desde el consabido Te Deum Laudamus hasta el paseo por las calles de la colonial ciudad de Cartago, y en la noche centelleante, su nombre en los castillos hechos de pólvora que ardían en la Plaza Mayor vociferando: ;Viva el Rey Fernando VII! Incluso en la representación escénica que se verificó en la noche del 23 de enero de 1809 , cuando por boca de uno de los personajes se colma de vivas al legítimo Rey de España e Indias: ... Viva y reine en todo/el Horbe nuestro invicto/Rey Fernando. En fin, el carácter propagandístico de los rituales regios se manifestaba en cada instante de la fiesta, desde el pronunciamiento del pregonero que anunciaba los actos de la jura con el acompañamiento de cajas de guerra, trompetas y chirimías, hasta las manifestaciones lúdicas que tenían lugar en las calles, $y$ especialmente, en la Plaza Mayor. Pero, hay más. El universo festivo fue diseñado de tal forma por el señor gobernador y las autoridades reales que permitiera no tan sólo legitimar la autoridad monárquica, sino el poder político local. Era uno de los momentos en que el grupo dominante $y$ los sectores subalternos entraban ANCR, Sección Histórica (SH), Serie: Municipal Cartago, Expediente 336, 1809, 117 v.

77

Baczko, Los imaginarios sociales, pp. 14-17. 
en contacto y compartían un espacio común de ocio y alegría, por encima de sus divisiones, desigualdades y diferencias. Pero también podía revelar la discontinuidad social que separaba a los unos de los otros en la sociedad colonial hispanoamericana.

El 7 de febrero de 1809, pocos días después de concluidas las celebraciones en honor de Fernando VII, el Gobernador Acosta recibía dos medallas grabadas con el busto — de perfil- del "Rey Amado", las cuales fueron enviadas por las autoridades del Ayuntamiento de la ciudad de Santiago de Guatemala, dada la lealtad demostrada por los "buenos vasallos" de la Provincia de Costa Rica; $y$ a la vez, le informaban que urgía nombrar un diputado ante las Cortes Españolas, convocadas con diligencia extraordinaria para iniciar labores en Cádiz en $1810^{78}$. Conviene agregar que las muestras de veneración por Fernando VII no se limitaron solamente a las citadas fiestas, sino que trascendieron aún más allá, pues el 26 de mayo de ese mismo año se dispuso que la noche del 29, víspera del día del santo del monarca, San Fernando Rey, los vecinos de Cartago debían de iluminar sus casas y calles, como era costumbre en tales ocasiones, pero con el mayor fervor y entusiasmo. Y, durante el cautiverio de Fernando VII en Francia, los costarricas celebraron la Constitución de Cádiz, entendiendo —igual que los súbditos peninsulares e hispanoamericanos-que el reconocimiento de la "Sabia Constitución" era compatible con el juramento otorgado años antes al deseado Rey. Asimismo, el Muy Noble y Leal Ayuntamiento de Cartago acató con beneplácito una Real Orden que disponía que el 2 de mayo de 1814 ameritaba celebrarse, con júbilo, el aniversario de los "Mártires de la Patria", es decir, el inicio de la Guerra de Independencia de la España invadida por los franceses ${ }^{79}$. Del mismo modo, cuando en 1814 Fernando VII recupera el trono

Fernández, La Plaza Mayor, p. 86.

No obstante, existía conciencia entre los "costarricas" de que el regreso de Fernando VII al trono de España e Indias significaba un punto de ruptura, un antes y un después. Véase: Guevara, de España, restaura el absolutismo, disuelve las Cortes de Cádiz y toda la obra legislativa gaditana, en la más "apartada", "leal" y "sumisa" Provincia de Costa Rica, con el mismo innegable regocijo, se juró fidelidad al Monarca con jornadas festivas, una misa solemne de acción de gracias en la Iglesia Mayor y un paseo a caballo con la asistencia de todas las autoridades y vecinos de más lustre, rodeados de indígenas, negros y mestizos, para manifestar al mundo ... que es cosa racional que un vasallo esté dispuesto á perder la vida antes de faltar al juramento de fidelidad a su Monarca. Eran en fin, ¡los vasallos perfectos!

El "patriarcal" Gobernador Juan de Dios de Ayala (quien administró la Provincia de Costa Rica entre diciembre de 1810 y junio de 1819), en una carta dirigida a don José de Bustamante y Guerra, Capitán General del Reino de Guatemala (1811-1818), confesaba con una complacencia que no se molestó en disimular:

... me es imposible explicar á Vuestra Excelencia lo gustoso que fué para mi corazón ese memorable día, que no olvidaré jamás de mi memoria, al oír lo que victoreaban al Rey... clérigos, religiosos, capitulares, militares $y$ hombres $y$ mujeres de todas clases... ${ }^{80}$

Sin embargo, la ironía de la historia de las fiestas reales de la jura de Fernando VII, en el Cartago de 1809, se evidenció unos años más tarde: en 1833, el óbito de don Fernando pasó prácticamente inadvertido entre los antiguos súbditos de la otrora Provincia de Costa Rica, quienes estaban ahora más imbuidos por las

\footnotetext{
"Fiestas profanas", pp.74 y 81. Juan Rafael Quesada Camacho, "El ideario de la Revolución Francesa", pp. 138-139.

80 Este informe fue enviado a la Presidencia de la Real Audiencia de Guatemala. Citado en: Iván Molina Jiménez, "Imagen de lo imaginario. Introducción a la historia de las mentalidades colectivas", Elizabeth Fonseca Corrales, comp., Historia: teoría y método, Editorial Universitaria Centroamericana, San José, 1989, p. 181.
} 
luchas intestinas en el seno de la República Federal de Centroamérica y el deseo de autonomía ${ }^{81}$.

\section{FUENTES PRIMARIAS MANUSCRITAS}

Archivo Nacional de Costa Rica (ANCR), Sección Histórica (SH), Serie: Complementario Colonial, Expedientes 991, 1102, 1968 (1808) y 919, 993, 994, 2050, 5339 (1809).

Archivo Nacional de Costa Rica (ANCR), Sección Histórica (SH), Serie: Municipal Cartago, Expediente Nro. 336, 1809.

\section{FUENTES PRIMARIAS IMPRESAS}

Archivo Nacional de Costa Rica (ANCR). «Actas del Cabildo de Cartago 1800-1810». Revista de los Archivos Nacionales. Año XXIII (1-6), enero-junio de 1959: 7-174.

Sobre estos aspectos, véase: Víctor Hugo Acuña Ortega, "Las concepciones de la comunidad política en Centroamérica en tiempos de la Independencia (1820-1823)", Francisco Colom González, ed. Relatos de nación. La construcción de las identidades nacionales en el mundo hispánico, Volumen I, Iberoamericana-Vervuet, 2005, pp. 251-273. Manuel Calderón Hernández, "De la Independencia a la Federación (18211838)", Ana María Botey Sobrado, coord., Costa Rica: desde las sociedades autóctonas hasta 1914. Editorial de la Universidad de Costa Rica, San José, 2002, pp. 209-227. Yolanda Dachner Trujillo, "Centroamérica: una nación antigua en la modernidad republicana", Anuario de Estudios Centroamericanos, 24 (1-2), 1998, pp. 7-20. Jordana Dym, "La soberanía de los pueblos: ciudad e independencia en Centroamérica, 1808-1823", Jaime Rodríguez, coord., Revolución, independencia y las nuevas naciones de América, Fundación MAPFRE-TAVERA, Madrid, 2005, pp. 309-337. Jordana Dym," Soberanía transitiva y adhesión condicional: lealtad e insurrección en el Reino de Guatemala, 1808-1811", Araucaria. Revista de Filosofía, Política y Humanidades, 18, 2007, pp. 196-219. Arturo Taracena Arriola, "Reflexiones sobre la Federación Centroamericana, 1823-1840", Revista de Historia, 2, 1992-1993, pp. 4-12.
Archivo Nacional de Costa Rica (ANCR). Álbum de Figueroa. Tomos I y II. 1850-1900.

Sección Documental: "Teatro Colonial”. Revista de Historia 34, julio-diciembre. 1996: 179-221.

\section{FUENTES SECUNDARIAS}

\section{BIBLIOGRAFÍA GENERAL}

Acuña León, María de los Ángeles y Doriam Chavarría. "El mestizaje: La sociedad multirracial en la ciudad colonial de Cartago. 1738-1821". [Tesis de Licenciatura en Historia]. San José. Universidad de Costa Rica, 1991.

Acuña Ortega, Víctor Hugo. "Las concepciones de la comunidad política en Centroamérica en tiempos de la Independencia (1820-1823)". Francisco Colom González (ed). Relatos de nación. La construcción de las identidades nacionales en el mundo hispánico Vol. I. Iberoamericana-Vervuet, 2005: 251-273.

Alvarenga Venotulo, Patricia."Resistencia campesina $y$ formación del mercado de bienes básicos. Cartago. 1750-1820”. Revista de Historia 31, enero-junio. 1995: 41-67.

Avendaño Rojas, Xiomara. "Las características de la ciudadanía en Centroamérica durante el siglo XIX. Estudio de los distritos electorales de Quetzaltenango y Granada". Revista de Historia 5-6. 1995: 20-29.

Baczko, Bronislaw. Los imaginarios sociales. Memorias y esperanzas colectivas. Buenos Aires: Ediciones Nueva Visión, 2005.

Bajtin, Mijail. La cultura popular en la Edad Media y el Renacimiento: El contexto 
de François Rabelais. Madrid: Alianza Editorial, 1999.

Balandier, Georges. El poder en escenas: de la representación del poder al poder de la representación. Barcelona: Paidós, 1994.

Bauer, Arnold. Somos los que compramos. Historia de la cultura material en América Latina. México: Taurus, 2002.

Benavides Murillo, Clotilde. "Reflexiones sobre la formación y función social de los artesanos en Cartago en el siglo XVIII". Revista Estudios 18-19. 2004-2005: 25-38.

Breña, Roberto. El primer liberalismo espanol y los procesos de emancipación de América, 1808-1824. Una revisión historiográfica del liberalismo hispánico. México: El Colegio de México. 2006.

Calderón Gómez, Juan Carlos. "Moros y Cristianos en Cartago (Baile de Conquista)". Escena, 13. 27. 1991: 20-25.

Calderón Hernández, Manuel. "De la Independencia a la Federación (18211838)". Botey Sobrado, Ana María, Costa Rica: desde las sociedades autóctonas hasta 1914. San José. Editorial de la Universidad de Costa Rica, 2002: 209-227.

Cañedo Gamboa, Sergio. Los festejos septembrinos en San Luis Potosí. Protocolo, discurso y transformaciones, 1824-1847. México: El Colegio de San Luis, 2001.

Cañeque, Alejandro. "De sillas y almohadas o de la naturaleza ritual del poder en la Nueva España de los siglos XVI y XVII". Revista de Indias LXIV. 232. 2004: 609-634.

Cárdenas Gutiérrez, Salvador. "De las Juras Reales al Juramento Constitucional: Tradición e innovación en el ceremonial novohispano, 1812-1820". [En línea], [consultado el 19 de marzo del 2007]. En: $<$ http:www.bibliojuridica.org/libros $>$.

Chacón Hidalgo. Manuel Benito. Monedas de Costa Rica. Reseña histórica. San José: Editorial de la Universidad de Costa RicaFundación Museos del Banco Central de Costa Rica, 2003.

Chartier, Roger. El mundo como representación. Historia cultural: entre práctica y representación. Barcelona: Gedisa Editorial, 1995.

Chavarría Jiménez, Sandra. "Las estructuras de dominación en Costa Rica: de la época colonial a los albores del Estado Nacional". Serie Nuestra Historia 6. San José: Editorial de la Universidad Estatal a Distancia, 1993.

Chiaramonti, Gabriella. Ciudadanía y representación en el Perú, 1808-1860: los itinerarios de la soberanía. Lima: Universidad Nacional Mayor de San Marcos, 2005.

Chust Calero, Manuel. "El Rey para el pueblo, la Constitución para la Nación”. Mínguez Cornelles, Víctor y Manuel Chust, eds. El Imperio sublevado. Monarquía y Naciones en España e Hispanoamérica. Madrid: Consejo Superior de Investigaciones Científicas. 2004: 225-254.

Colom González, Francisco. "El trono vacío. La imaginación política y la crisis constitucional de la Monarquía Hispánica”. Francisco Colom González, de. Relatos de nación. La construcción de las identidades nacionales en el mundo hispánico. Vol. I. Madrid. Iberoamericana-Vervuet, 2005: 23-50.

Dachner Trujillo, Yolanda. "Centroamérica: una nación antigua en la modernidad republicana". Anuario de Estudios Centroamericanos 24. 1-2. 1998: 7-20. 
Darnton, Robert. "Un burgués pone en orden su mundo: la ciudad como texto". La gran matanza de gatos y otros episodios en la historia de la cultura francesa. México. Fondo de Cultura Económica, 2000: 109-147.

Díaz Arias, David. "Invención de una tradición: La fiesta de la Independencia durante la construcción del Estado costarricense, 1821-1874". Revista de Historia 45, enerojunio 2002: 105-162.

Dym, Jordana. "La soberanía de los pueblos: ciudad e independencia en Centroamérica, 1808-1823", Rodríguez, Jaime, coord. Revolución, independencia y las nuevas naciones de América. Madrid: Fundación Mapfre-Tavera, 309-337.

"Soberanía transitiva y adhesión condicional: lealtad e insurrección en el Reino de Guatemala, 1808-1811". Araucaria. Revista de Filosofía, Politica y Humanidades 18. 2007: 196-219.

Estrada Molina, Ligia. "Don Tomás de Acosta: Gobernador de Costa Rica". [Tesis de Licenciatura en Historia]. San José: Universidad de Costa Rica, 1962.

Fajardo De Rueda, Marta. "La jura del Rey Carlos IV en la Nueva Granada". Anales del Instituto de Investigaciones Estéticas 74-75. 1999: 195-209.

Fernández Bonilla, León. Historia de Costa Rica durante la dominación española (1502-1821). San José: Editorial Costa Rica, 1975.

Fernández Esquivel, Franco. La Plaza Mayor: génesis de la nación costarricense. Cartago. Editorial Cultural CartaginesaUruk Editores SA. 1996.

Ferrer Valls, Teresa. "La fiesta en el Siglo de Oro: en los márgenes de la ilusión teatral". Teatro y fiesta del Siglo del Oro en tierras europeas de los Austrias. Madrid. SEACEX, 2003: 27-37.

Fonseca Corrales, Elizabeth y Enrique Barascout. "Historia de la Arquitectura colonial". Corrales, Elizabeth y José Enrique Garnier, eds. Historia de la Arquitectura en Costa Rica. San José. Fundación de Museos del Banco Central de Costa Rica, 1998: 81-149.

Frasquet Miguel, Ivana. "Alteza versus Majestad: el poder de la legitimidad en el Estadonación mexicano: 1810-1824". Mínguez Cornelles, Víctor y Manuel Chust, eds. El Imperio Sublevado. Monarquía y Naciones en España e Hispanoamérica. Madrid. Consejo Superior de Investigaciones Científicas, 2004: 255-276.

Garavaglia, Juan Carlos. "Del Corpus a los toros: fiesta, ritual y sociedad en el Río de la Plata colonial". Anuario del IEHS 16. 2001: 391-420.

Garrido Asperó, María José. Fiestas cívicas históricas en la Ciudad de México: 17651823. México: Instituto de Investigaciones Doctor José María Luis Mora, 2006.

Gayol, Víctor. "El retrato del Escondido. Notas sobre un retrato de jura de Fernando VII en Guadalajara”. Relaciones. Estudios de Historia y Sociedad 83. Verano de 2000: 151-181.

Gil Calvo, Enrique. El estado de fiesta. Feria, foro, corte y circo. Madrid: Espasa-Calpe, 1991.

Ginzburg, Carlo. "Representación. La palabra, la idea, la cosa". Ojazos de madera. Nueve reflexiones sobre la distancia. Barcelona. Ediciones Península, 2000: 85-103.

González Pérez, Marcos. "Sociabilidad y fiesta. Bogotá siglo XIX”. Historias 41, octubrediciembre, 1998: 113-121. 
Guerra, François-Xavier, et ál. Los espacios públicos en Iberoamérica. Ambigüedades y problemas. Siglos XVII-XIX. México: Fondo de Cultura Económica, 1998.

Guerra, François-Xavier. Modernidad e independencias. Ensayos sobre las revoluciones hispánicas. México: Fondo de Cultura Económica, 2000.

Guevara Salazar, Eva María. "Fiestas profanas en la sociedad colonial". Vida Cotidiana en la Colonia. 1680-1821. [Seminario de Graduación de Licenciatura en Historia]. San José. Universidad de Costa Rica, 1994: 48-183.

Gruzinski, Serge. La guerra de las imágenes. De Cristóbal Colón a Blade Runner. 1492-2019. México: Fondo de Cultura Económica, 1990.

Herrejón Peredo, Carlos. Del sermón al discurso cívico. México, 1760-1834. México: El Colegio de México-El Colegio de Michoacán, 2003.

Ibarra Rojas, Eugenia. Las manchas del jaguar: Huellas indigenas en la historia de Costa Rica (Valle Central, Siglos XVI-XX). San José: Editorial de la Universidad de Costa Rica, 1999.

Jiménez Oreamuno, Manuel De Jesús. "Fiestas Reales”. Noticias de Antaño. San José. Imprenta Nacional, 1946: 53-68.

Kantorowicz, Ernst H. Los dos cuerpos del Rey. Madrid: Alianza Universidad, 1985.

Landavazo, Marco Antonio. La máscara de Fernando VII. Discurso e imaginario monárquicos en una época de crisis. Nueva España. 1808-1822. México: El Colegio de México-Universidad Michoacana de San Nicolás de HidalgoEl Colegio de Michoacán, 2001.
"La sacralización del Rey. Fernando VII, la insurgencia novohispana y el derecho divino de los reyes". Revista de Indias LXI. 221. 2001: 67-90.

Lepetit, Bernard. "Comunidad ciudadana, territorio urbano y prácticas sociales", Historiografía francesa: corrientes temáticas y metodológicas recientes. México. Instituto de Investigaciones Doctor José María Luis Mora, 1997: 125-144.

Lynch, John. América Latina, entre colonia y nación. Barcelona: Editorial Crítica, 2001.

Madrigal Muñoz, Eduardo. "La elite colonial de cara a las instituciones coloniales, 1600-1708", [en línea], [consultado el 9 de enero del 2007]. En: <http:www. afehc-historia-centroamerica.org>.

Martínez Villa, Juana. "La fiesta regia en Valladolid de Michoacán. Política, sociedad y cultura en el México Borbónico". [Tesis de Maestría en Historia]. México: Instituto de Investigaciones Históricas. Universidad Michoacana de San Nicolás de Hidalgo, 2006.

Meléndez Chaverri, Carlos. "Las Villas Nuevas en la Costa Rica Borbónica”. Sibaja, Luis Fernando, et ál., Costa Rica Colonial. San José. Ediciones Guayacán, 1989: 165-177.

Mínguez Cornelles, Víctor. "Efímero Mestizo". Mínguez Cornelles, Víctor, et ál. Iberoamérica Mestiza. Encuentro de pueblos y culturas. SEACEX-Fundación Santillana, 2003: 49-65.

. "Fernando VII. Un rey imaginado para una nación inventada". Rodríguez, Jaime, coord. Revolución, independencia y las nuevas naciones de América. Madrid. Fundación MAPFRE-TAVERA, 2005: 193-213. 
Molina Jiménez, Iván. "Imagen de lo imaginario. Introducción a la historia de las mentalidades colectivas". Fonseca Corrales, Elizabeth, compa. Historia: teoría y métodos. San José. Editorial Universitaria Centroamericana, 1989: 179-224.

. Costa Rica (1800-1850). El legado colonial y la génesis del capitalismo. San José: Editorial de la Universidad de Costa Rica, 1991.

Molina Montes de Oca, Carlos. Y las mulas no durmieron... Los arrieros en Costa Rica. Siglos XVI al XIX. San José: Editorial de la Universidad Estatal a Distancia, 2005.

Moya Gutiérrez, Arnaldo. "La vida cotidiana en la Provincia de Costa Rica. 1750-1820". Botey Sobrado, Ana María, coorda. Costa Rica: desde las sociedades autóctonas hasta 1914. San José. Editorial de la Universidad de Costa Rica, 2002: 173-207.

Obregón Loría, Rafael. De nuestra historia patria: Las Autoridades Coloniales Superiores de Costa Rica. San José: Publicaciones de la Universidad de Costa Rica, 1979.

Osorio, Alejandra. "El Rey en Lima. El simulacro real y el ejercicio del poder en la Lima del diecisiete". Documento de Trabajo 140. Lima: Instituto de Estudios Peruanos, 2004.

Page, Carlos. "Las proclamaciones reales en Córdoba del Tucumán”. Revista Complutense de Historia de América 30. 2004: 77-94.

Pérez Brignoli, Héctor. Breve historia contemporánea de Costa Rica. México: Fondo de Cultura Económica, 1997.

Quesada Camacho, Juan Rafael. Educación y ciudadanía en Costa Rica de 1810 a 1821: del crepúsculo colonial al umbral de la modernidad. Editorial de la Universidad de Costa Rica, 2007.

. "El ideario de la Revolución Francesa en Cádiz: aproximación al estudio de la construcción de la nación costarricense". Revista del Archivo Nacional LXIX. 1-12. 2005: 105-155.

Rojas Nieto, Beatriz. Documentos para el estudio de la cultura política de la transición. Juras, poderes e instrucciones. Nueva España y la Capitanía General de Guatemala. 1808-1820. México: Instituto de Investigaciones Doctor José María Luis Mora, 2005.

Ross González, Marjorie. Entre el comal y la olla. Fundamentos de gastronomía costarricense. San José: Editorial de la Universidad Estatal a Distancia, 2001.

Ruiz Medrano, Carlos Rubén. Fiestas y procesiones en el mundo colonial novohispano. Los conflictos de preeminencia $y$ una sátira carnavalesca del siglo XVIII. México: El Colegio de San Luis, 2002.

Sáenz Carbonell, Jorge Francisco. “¡Viva nuestro Rey Fernando! (Albores del teatro costarricense)". Revista Nacional de Cultura 27. 1995: 55-81.

Solórzano Fonseca, Juan Carlos y Claudia Quirós Vargas. Costa Rica en el siglo XVI. Descubrimiento, exploración y conquista. San José. Editorial de la Universidad de Costa Rica. 2006.

Solórzano Fonseca, Juan Carlos. "La sociedad colonial 1575-1821". Botey Sobrado, Ana María, coorda, Costa Rica: desde las sociedades autóctonas hasta 1914. San José: Editorial de la Universidad de Costa Rica, 2002: 115-172. 
Taracena Arriola, Arturo. "Reflexiones sobre la Federación Centroamericana, 18231840". Revista de Historia 2. 1992-1993: 4-12.

Valenzuela Márquez, Jaime. "De las liturgias del poder al poder de las liturgias: para una antropología política de Chile colonial". Historia 32. 1999: 575-615.
Zárate Toscano, Verónica. "Del regocijo a la penitencia o del carnaval a la cuaresma en la Ciudad de México en el siglo XIX". Gonzalbo Aizpuru, Pilar y Verónica Zárate Toscano, coordas. Gozos y sufrimientos en la historia de México. México. El Colegio de México-Instituto de Investigaciones Dr. José María Luis Mora, 2007: 203-234. 
